\title{
WATER-POWER RESOURCES OF THE MCKENZIE RIVER AND ITS TRIBUTARIES, OREGON
}

\author{
By Benjamin E. Jones and Harold T. Stearns
}

\section{SUMMARY}

The McKenzie River is a valuable power stream from Clear Lake to Coburg Bridge, which is only 3 miles above its mouth. It has a large fall and well-sustained flow, but storage on the main stream would be expensive. On Olallie Creek, Lost Creek, Horse Creek to the mouth of Separation Creek, Separation Creek from its mouth to Mesa Creek, and the Roaring River, tributary to the South Fork of the McKenzie River, there are a number of power sites that can be economically developed when a market is available. The South Fork of the McKenzie River has some potential power, but it would be more expensive to develop than that on the other streams. The Blue River possesses no advantageous power sites, but a reservoir might be built on it to store water for use at sites on the McKenzie River. The Mohawk River has no power value.

Clear Lake is of little value as a reservoir because of leakage. Two proposed reservoir sites on the McKenzie River, the Paradise site and the Eugene municipal site No. 3, would have a total capacity of 197,000 acre-feet, of which 47,000 acrefeet would be required in the bottom of the reservoirs to create head, leaving a net capacity of 150,000 acre-feet. A proposed reservoir on the Blue River would have a total capacity of 59,000 acre-feet, and the Mesa site, at the head of Separation Creek, would have a capacity of 5,000 acre-feet.

Only one power site was being utilized at the time of the field examination in 1926. It is a plant with a net head of 45 feet and a capacity of 4,300 horsepower owned by the city of Eugene. A second plant for the city of Eugene is under construction near Leaburg. It will have an initial capacity of 10,000 horsepower and an ultimate capacity of 20,000 horsepower.

The water power of the McKenzie River is assumed to be capable of development at 16 sites, including the two being utilized by the city of Eugene. The potential power at these sites without storage is 207,000 horsepower for 90 per cent of the time and 327,000 horsepower for 50 per cent of the time. With storage at the four proposed reservoir sites the potential power is increased to 243,000 horsepower for 90 per cent of the time, with no change in the power available 50 per cent of the time.

The water power on tributaries of McKenzie River is assumed to be capable of development at 18 sites. The potential power at these sites without storage is 82,600 horsepower for 90 per cent of the time and 117,000 horsepower for 50 per cent of the time. As only 5,000 acre-feet of storage would be available on the tributaries, this would not appreciably affect the flow available 90 per cent of the time, although it would increase the power available 100 per cent of the time.

The total potential power of the McKenzie River Basin without storage is 290,000 horsepower for 90 per cent of the time and 444,000 horsepower for 50 per cent of the time. With storage at the four proposed reservoir sites the potential power for 90 per cent of the time would be increased to 325,000 horsepower, but the potential power for 50 per cent of the time would remain unchanged.

The following table summarizes the data regarding the two power sites developed by the city of Eugene and the proposed power sites in the McKenzie River Basin: 
Water-power resources of the McKenzie River Basin

[Estimates of power based on static head and over-all plant efficiency of 70 per cent]

\begin{tabular}{|c|c|c|c|c|c|c|c|c|c|c|c|c|}
\hline \multirow{3}{*}{ Index No. } & \multirow{3}{*}{ Name of site } & \multirow{3}{*}{ Stream } & \multicolumn{5}{|c|}{ With existing flow } & \multicolumn{5}{|c|}{ With regulated flow } \\
\hline & & & \multirow{2}{*}{$\begin{array}{c}\text { Gross } \\
\text { head } \\
\text { (H) } \\
\text { (feet) }\end{array} \mid$} & \multicolumn{2}{|c|}{$\begin{array}{c}\text { Flow (second- } \\
\text { feet) }\end{array}$} & \multicolumn{2}{|c|}{ Horsepower } & \multirow{2}{*}{$\begin{array}{c}\text { Gross } \\
\text { head } \\
\text { (H) } \\
\text { (feet) }\end{array}$} & \multicolumn{2}{|c|}{$\begin{array}{c}\text { Flow (second- } \\
\text { feet) }\end{array}$} & \multicolumn{2}{|c|}{ Horsepower } \\
\hline & & & & $\begin{array}{c}90 \text { per } \\
\text { cent of } \\
\text { time } \\
(\mathrm{Q} 90)\end{array}$ & $\begin{array}{l}50 \text { per } \\
\text { cent of } \\
\text { time } \\
(\mathrm{Q} 50)\end{array}$ & 0.08HQ90 & $0.08 \mathrm{H} Q 50$ & & $\begin{array}{l}90 \text { per } \\
\text { cent of } \\
\text { time }\end{array}$ & $\begin{array}{c}50 \text { per } \\
\text { cent of } \\
\text { time }\end{array}$ & 0.08HQ90 & 0.08HQ50 \\
\hline 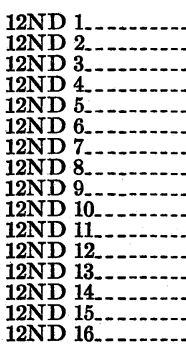 & $\begin{array}{l}\text { Upper Falls } \\
\text { Middle Falls. } \\
\text { Lower Falls } \\
\text { Smith River } \\
\text { Deer Creek } \\
\text { Belknap } \\
\text { Paradise- } \\
\text { McKenzie Bridge } \\
\text { Combination } \\
\text { Eugene municipal No. } 3 . \\
\text { Vida } \\
\text { Eugene municipal No. } 2 \\
\text { Deerhorn a } \\
\text { Eugene municipal No. } 1 \text { bo } \\
\text { Hayden Bridge } \\
\text { Coburg }\end{array}$ & 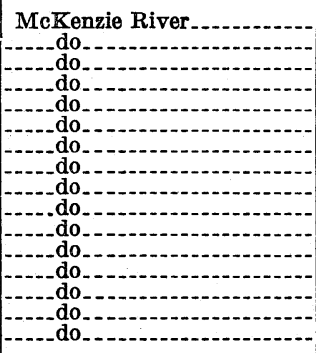 & $\begin{array}{r}250 \\
150 \\
270 \\
310 \\
170 \\
300 \\
145 \\
225 \\
140 \\
170 \\
100 \\
90 \\
45 \\
55 \\
90 \\
50\end{array}$ & $\begin{array}{r}242 \\
322 \\
480 \\
530 \\
820 \\
870 \\
1,160 \\
1,410 \\
1,680 \\
1,750 \\
1,750 \\
1,780 \\
1,790 \\
1,790 \\
1,790 \\
1,810\end{array}$ & $\begin{array}{r}340 \\
440 \\
660 \\
730 \\
1,120 \\
1,190 \\
1,590 \\
1,940 \\
2,290 \\
3,150 \\
3,150 \\
3,350 \\
3,550 \\
3,550 \\
3,500 \\
3,590\end{array}$ & $\begin{array}{r}4,840 \\
3,860 \\
10,400 \\
13,100 \\
11,100 \\
20,900 \\
13,400 \\
25,400 \\
18,800 \\
23,800 \\
14,000 \\
12,800 \\
6,440 \\
7,880 \\
12,900 \\
7,440\end{array}$ & $\begin{array}{r}6,800 \\
5,280 \\
14,200 \\
18,100 \\
15,200 \\
28,600 \\
18,400 \\
34,900 \\
25,600 \\
42,800 \\
25,200 \\
24,100 \\
12,800 \\
15,600 \\
25,200 \\
14,400\end{array}$ & $\begin{array}{r}111 \\
225 \\
140 \\
138 \\
100 \\
90 \\
45 \\
55 \\
90 \\
50\end{array}$ & \begin{tabular}{|r|} 
\\
\hdashline \\
\hdashline \\
\hdashline 1,300 \\
1,550 \\
1,820 \\
2,600 \\
2,600 \\
2,640 \\
2,650 \\
2,650 \\
2,650 \\
2,670
\end{tabular} & \begin{tabular}{r}
$-1,590$ \\
\hdashline 1,940 \\
2,290 \\
3,150 \\
3,150 \\
3,350 \\
3,550 \\
3,550 \\
3,500 \\
3,590
\end{tabular} & $\begin{array}{r}4,840 \\
3,860 \\
10,400 \\
13,100 \\
11,100 \\
20,900 \\
11,500 \\
27,900 \\
20,400 \\
28,700 \\
20,800 \\
19,000 \\
9,540 \\
11,600 \\
19,000 \\
10,700\end{array}$ & $\begin{array}{r}6,800 \\
5,280 \\
14,200 \\
18,100 \\
15.200 \\
28,600 \\
18.400 \\
34,900 \\
25,600 \\
42,800 \\
25,200 \\
24,100 \\
12,800 \\
15,600 \\
25,200 \\
14,400\end{array}$ \\
\hline & Total McKenzie River.- & 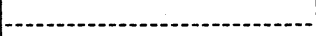 & $-\ldots$ & -...... & $-\ldots$ & 207,060 & 327,180 & 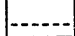 & $-\cdots$ & - & 243,340 & 327,180 \\
\hline 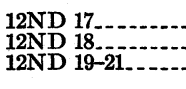 & $\begin{array}{l}\text { Olallie Creek } \\
\text { Lost Creek } \\
\text { Horse Creek above Separation }\end{array}$ & $\begin{array}{l}\text { Olallie Creek } \\
\text { Lost Creek } \\
\text { Horse Creek }\end{array}$ & $\begin{array}{r}140 \\
250 \\
-\end{array}$ & $\begin{array}{l}165 \\
225\end{array}$ & $\begin{array}{l}200 \\
300\end{array}$ & $\begin{array}{l}1,850 \\
4,500 \\
4,000\end{array}$ & $\begin{array}{l}2,240 \\
6,000 \\
8,000\end{array}$ & - & & & $\begin{array}{l}1,850 \\
4,500 \\
4,000\end{array}$ & $\begin{array}{l}2,240 \\
6,000 \\
8,000\end{array}$ \\
\hline 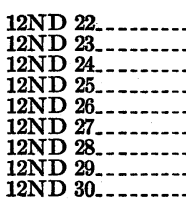 & $\begin{array}{l}\text { Foley Springs } \\
\text { Mouth of Horse Creek } \\
\text { Mesa Creek. } \\
\text { Harvey Creek } \\
\text { Rainbow Creek } \\
\text { Elk Creek } \\
\text { Augusta Creek } \\
\text { Hardy Creek } \\
\text { Slide Creek. }\end{array}$ & 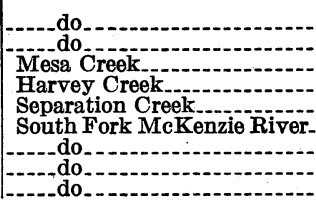 & $\begin{array}{r}280 \\
300 \\
1,450 \\
850 \\
720 \\
250 \\
430 \\
290 \\
220\end{array}$ & $\begin{array}{r}275 \\
280 \\
100 \\
125 \\
186 \\
70 \\
180 \\
185 \\
185\end{array}$ & $\begin{array}{l}400 \\
410 \\
125 \\
160 \\
235 \\
105 \\
270 \\
280 \\
285\end{array}$ & $\begin{array}{r}6,160 \\
6,720 \\
11,600 \\
8,500 \\
10,700 \\
1,400 \\
6,200 \\
4,300 \\
3,250\end{array}$ & $\begin{array}{r}8,960 \\
9,840 \\
14,500 \\
10,900 \\
13,500 \\
2,100 \\
9,300 \\
6,500 \\
5,000\end{array}$ & 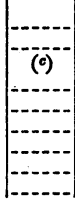 & 100 & 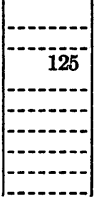 & $\begin{array}{r}6,160 \\
6,720 \\
10,400 \\
8,500 \\
10,700 \\
1,400 \\
6,200 \\
4,300 \\
3,250\end{array}$ & $\begin{array}{r}\mathbf{8}, 960 \\
\mathbf{9}, 840 \\
13,500 \\
10,900 \\
13,500 \\
2,100 \\
9,300 \\
6,500 \\
5,000\end{array}$ \\
\hline
\end{tabular}




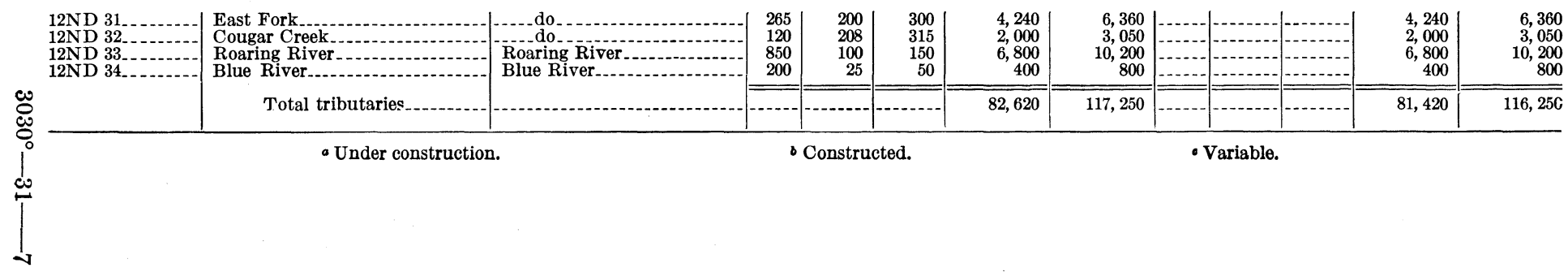




\section{INTRODUCTION}

This report is a study of the power resources of the McKenzie River and its tributaries, prepared primarily to determine the probable use of the public lands in the basin in connection with the utilization of the power resources. For this purpose it is not necessary to make detailed studies of individual sites or estimates of costs, but it is essential to formulate a general plan of development in order to determine the power available; and if the water supply, stream slope, and topography are such that the probable scheme of development can be determined with fair accuracy, a definite determination can be made as to the power value of individual tracts of public land. For that reason topographic maps of the main river were prepared and geologic examinations were made at three proposed dam sites. Gaging stations to determine the discharge of the rivers have been maintained at several points, which are listed elsewhere in this report. Many miscellaneous measurements of stream flow have been obtained, and three temporary gaging stations were maintained to determine the low-water flow on tributaries. A topographic survey of the McKenzie River, the South Fork of the McKenzie River to mile 18, the Blue River to mile 9, Horse Creek to mile 10, and Lost Creek to mile 4 was made in 1925 by C. W. H. Nessler, topographic engineer of the United States Geological Survey. Separation Creek, tributary to Horse Creek, from the mouth to a point 2 miles above Mesa Creek, and Mesa Creek from the mouth to a point 2 miles upstream; were surveyed in 1927 by R. O. Helland, land classifier. The geology of the Martins Rapids dam site, the Eugene municipal site No. 3, and the outlet of Clear Lake was examined by H. T. Stearns in 1926. A field examination of the river basin was made during the summer of 1926 by B. E. Jones. Previous reports on the water power of the McKenzie River by E. C. LaRue, hydraulic engineer, and the recommendations of F. F. Henshaw, district engineer, have been drawn upon in the preparation of this report.

All the data gathered in various ways by members of the Geological Survey have been combined and studied to determine a feasible method of developing the power resources of the basin.

\section{GEOGRAPHY}

The McKenzie River, tributary to the Willamette River at Eugene, Oreg., has a length of 86 miles from its mouth to the outlet of Clear Lake, its source, and the total drainage area above the gaging station at Hendricks Bridge is 1,100 square miles. The basin is narrow, and the upper section, above the Blue River (see pl. 2) is mountainous and heavily timbered, with little chance for future agricultural development. Even down as far as Leaburg there is little agriculture, and practically no water is diverted for irrigation. The river is largely 
U. S. GEOLOGICAL SURVEY

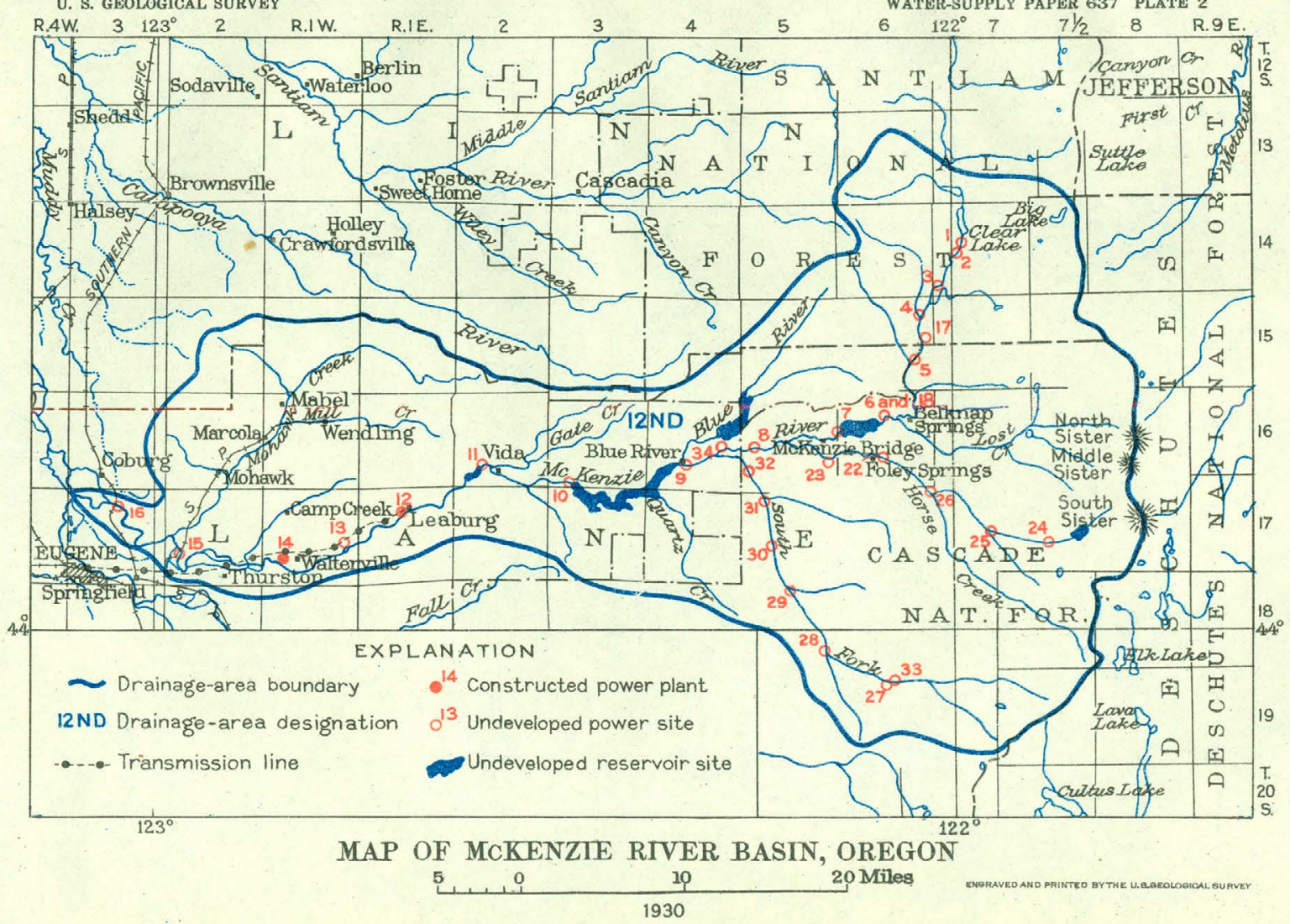


spring-fed near its source; it has a large flow during the low-water season and considerable power possibilities. Power from this stream now supplies the city of Eugene and could be transmitted to Portland, which is 124 miles north by State highway. The Middle Fork of the Willamette River flows to the south of the McKenzie, and the Santiam River to the north. Plate 2 shows the relative location of the basin and is an index to the location of the power sites, which are numbered 1,2 , etc. The drainage-area designation is $12 \mathrm{ND}$, the number 12 designating the North Pacific slope drainage area, $12 \mathrm{~N}$ the Willamette River Basin, and 12ND the McKenzie River Basin.

Clear Lake is fed by a large spring near its head and other springs in its bottom. Above Clear Lake there is, during the rainy season, a shallow lake called Fish Lake, into which some small creeks flow and which in turn drains into Clear Lake. A mile below the outlet of Clear Lake are the Upper Falls, with a drop of 120 feet, and a quarter of a mile farther down are the Middle Falls, with a drop of 70 feet. In the 3-mile stretch between the Middle Falls and the Lower Falls the flow of the river is largely subterranean; during the summer the bed is dry for a long distance above the Lower Falls, but the stream reappears, apparently in full volume, in a pool below the falls. About 9 miles below Clear Lake Olallie Creek, a short spring-fed stream, discharges more than 100 second-feet at low stages into the McKenzie River. Other spring-fed tributaries are Horse Creek and the South Fork of the McKenzie. The Blue River is not spring-fed and has a low flow during the summer. The low-water flow of Horse Creek comes mostly from Separation Creek, which rises on the edge of the Three Sisters and has a fall of 3,360 feet in a little over 12 miles. The South Fork of the McKenzie River has a well-sustained flow and sufficient fall to make it a valuable power stream. Plate 3 shows a profile of the McKenzie River and its principal tributaries.

\section{GEOLOGY}

A brief summary of the principal events in the geologic history of western Oregon and of the areal distribution of the chief formations is desirable as a setting for a description of the geology of the reservoirs and dam sites.

Little is known of the geologic history of this region before Cretaceous time, for the earlier sediments have been completely metamorphosed to schist, slate, and serpentine. These rocks are exposed along the lower part of the Rogue River in Jackson, Josephine, and Curry Counties.

The Cretaceous period was ushered in with great intrusions of granodiorite and other igneous rocks and with extensive movements of the crust. During this period the northern and central parts of western Oregon lay below sea level and received sedimentary deposits, 
which were later consolidated to conglomerate, shale, and sandstone. These beds were subjected to considerable folding, which has altered their original character and tilted them at steep angles. Many of the rugged canyons and consequently the sites of dams and reservoirs are in the intrusive rocks of this period. In general these intrusive rocks form excellent sites, from the point of view of both the geologist and the engineer, and they are as a whole better than the sites in any of the later formations. The granodiorite, diabase, and other intrusive rocks of this period cooled under the weight of overlying sedimentary deposits and consequently do not have the porous structure and leaky contacts and joints that characterize so many of the later, extrusive rocks. Moreover, in crushing strength most of the intrusive rocks are equal to granite, and all are sufficiently strong to support large structures.

The chief event during the Tertiary period was the building of the Cascade Range by uplift and volcanic action. In the early part of the period extensive beds of sandstone and conglomerate were deposited in marine waters, and thick dikes and sills of basaltic lava were intruded into the sediments. The sites located in the sedimentary rocks of this period are generally good, although there may be a slight leakage along bedding planes. During the later half of Tertiary time marine deposition continued over northwestern Oregon, interrupted by occasional epochs of uplift. The late Tertiary and the succeeding Pleistocene witnessed great volcanic activity. Enormous volcanoes along the Cascade Range poured forth thick lava flows and emitted showers of pumice. Many of the lava flows coursed down river valleys and partly filled them. Since that time the rivers have excavated portions of these lava fills and formed narrow canyons with vertical walls of lava. Most of this rock is fractured and fissured, and much of it covers ancient gravel beds, through which impounded water might escape rapidly. Although some of these canyons in lava offer excellent dam sites so far as purely physical form is concerned, such places are treacherous for storing water, because of probable leakage. Late Tertiary pumice deposits cover wide areas, especially in the vicinity of Crater Lake, and form a thick flow in the Rogue River Valley. The misplaced drainage and concealed channels caused by this volcanism make reservoir sites in these deposits hazardous.

During Pleistocene time the high peaks of the Cascade Range were covered with glaciers, which moved down the valleys of most of the larger streams. While these glaciers existed the master streams were heavily loaded with débris and aggraded their valleys. Later erosion excavated valleys in the glacial gravel, leaving the remnants of the fill as terraces. Dam sites located in this material are poor because of the amount of excavation necessary to reach bedrock. 


\section{CLIMATE}

The climate of the McKenzie River Basin is mild, the temperature seldom dropping below the freezing point for any long period. Even in the upper part of the basin the winters are not severe, though there is considerable snow.

Above Vida the mean annual rainfall ranges between 70 and 100 inches; below Vida it decreases rapidly to 38.5 inches at Eugene. In all of western Oregon there is heavy precipitation during the winter and spring but very little in the summer and early fall. The flow of the McKenzie River is sustained during this period of low precipitation by the discharge of large springs, as well as by some water coming from the melting glaciers on the Three Sisters.

Mean temperature $\left({ }^{\circ} \mathrm{F}.\right)$ in the McKenzie River Basin

\begin{tabular}{|c|c|c|c|c|c|c|c|}
\hline \multirow[b]{2}{*}{ Month } & \multirow[b]{2}{*}{ Eugene. } & \multicolumn{2}{|c|}{ McKenzie Bridge } & \multirow[b]{2}{*}{ Month } & \multirow[b]{2}{*}{ Eugene } & \multicolumn{2}{|c|}{ McKenzie Bridge } \\
\hline & & Mean & $\begin{array}{c}\text { Mean } \\
\text { minimum, } \\
1902-1908\end{array}$ & & & Mean & $\underset{\text { minimum }}{\text { Mean }}$ \\
\hline \multirow{2}{*}{$\begin{array}{l}\text { January } \\
\text { February } \\
\text { March } \\
\text { April... } \\
\text { May } \\
\text { June.-. } \\
\text { July } \\
\text { August... }\end{array}$} & \multirow{2}{*}{$\begin{array}{l}40.3 \\
42.8 \\
45.8 \\
50.5 \\
55.2 \\
60.2 \\
65.8 \\
65.6\end{array}$} & \multirow{2}{*}{$\begin{array}{l}35.4 \\
39.0 \\
43.2 \\
49.0 \\
54.0 \\
58.7 \\
64.8 \\
63.0\end{array}$} & \multirow{2}{*}{$\begin{array}{r}0 \\
8 \\
10 \\
22 \\
25 \\
33 \\
29 \\
32\end{array}$} & \multirow{2}{*}{\begin{tabular}{|} 
September \\
October \\
November \\
December \\
Yearly mean \\
Altitude (feet)
\end{tabular}} & $\begin{array}{l}60.3 \\
53.2 \\
46.3 \\
40.9 \\
\end{array}$ & $\begin{array}{l}57.0 \\
51.6 \\
42.5 \\
36.3 \\
\end{array}$ & $\begin{array}{l}22 \\
24 \\
19 \\
12 \\
\end{array}$ \\
\hline & & & & & $\begin{array}{r}52.2 \\
450\end{array}$ & $\begin{array}{r}49.5 \\
1,375\end{array}$ & 1,375 \\
\hline
\end{tabular}

Mean monthly and yearly precipitation, in inches, in the McKenzie River Basin

\begin{tabular}{|c|c|c|c|c|c|c|c|}
\hline Month & $\begin{array}{c}\text { Eugene, } \\
\text { 1908-1923 }\end{array}$ & $\begin{array}{c}\text { Vida, } \\
1913-1916\end{array}$ & $\begin{array}{c}\text { McKenzie } \\
\text { Bridge, } \\
\text { 1902-1913 }\end{array}$ & Month & $\begin{array}{l}\text { Eugene, } \\
\text { 1908-1923 }\end{array}$ & $\begin{array}{c}\text { Vida, } \\
1913-1916\end{array}$ & $\begin{array}{l}\text { McKenzie } \\
\text { Bridge, } \\
\text { 1902-1913 }\end{array}$ \\
\hline \multirow{2}{*}{$\begin{array}{l}\text { January } \\
\text { February } \\
\text { March } \\
\text { April } \\
\text { May } \\
\text { June } \\
\text { July } \\
\text { August. }\end{array}$} & \multirow{2}{*}{$\begin{array}{r}5.65 \\
4.25 \\
3.59 \\
2.45 \\
2.38 \\
1.65 \\
.53 \\
.39\end{array}$} & \multirow{2}{*}{$\begin{array}{r}10.16 \\
7.19 \\
8.85 \\
4.84 \\
5.09 \\
4.23 \\
1.80 \\
.46\end{array}$} & \multirow{2}{*}{$\begin{array}{r}10.30 \\
8.65 \\
6.82 \\
4.05 \\
4.49 \\
2.76 \\
1.13 \\
1.03\end{array}$} & \multirow{2}{*}{\begin{tabular}{|} 
September. \\
October \\
November... \\
December.... \\
Yearly mean.-. \\
Altitude (feet)
\end{tabular}} & $\begin{array}{l}2.08 \\
2.68 \\
6.31 \\
5.19 \\
\end{array}$ & $\begin{array}{r}3.36 \\
4.54 \\
11.34 \\
7.00 \\
\end{array}$ & $\begin{array}{r}2.81 \\
5.66 \\
12.25 \\
10.13 \\
\end{array}$ \\
\hline & & & & & $\begin{array}{r}37.15 \\
450\end{array}$ & $\begin{array}{r}68.86 \\
780\end{array}$ & $\begin{array}{l}70.08 \\
1,375\end{array}$ \\
\hline
\end{tabular}

\section{FACTORS AFFECTING HYDRAULIC STRUCTURES}

The little ice that forms on the streams in the McKenzie River Basin would not cause much trouble in the operation of power plants. The rivers carry practically no silt except during floods, and floating débris could be removed at the dams.

Irrigation does not appreciably affect the flow of the McKenzie River. In the upper section there is little cultivable land, and even in the lower stretches, where the valley is wider, little effort is made to divert water for irrigation. Water is diverted for municipal purposes by the city of Eugene, but this is well down toward the 
mouth of the river. There is no navigation on the McKenzie River, and the Willamette River, to which it is tributary, is navigable only as far up as Oregon City.

\section{ANNUAL YIELD AND MINIMUM FLOW}

The estimates of power available at different sites are based on the normal flow of the stream for 50 per cent and 90 per cent of the time (expressed as Q50 and Q90). The principal gaging stations on whose records the estimates are based are at the outlet of Clear Lake, at McKenzie Bridge, at Vida, and at Hendricks Bridge, above Springfield. (See fig. 1.) Miscellaneous discharge records on

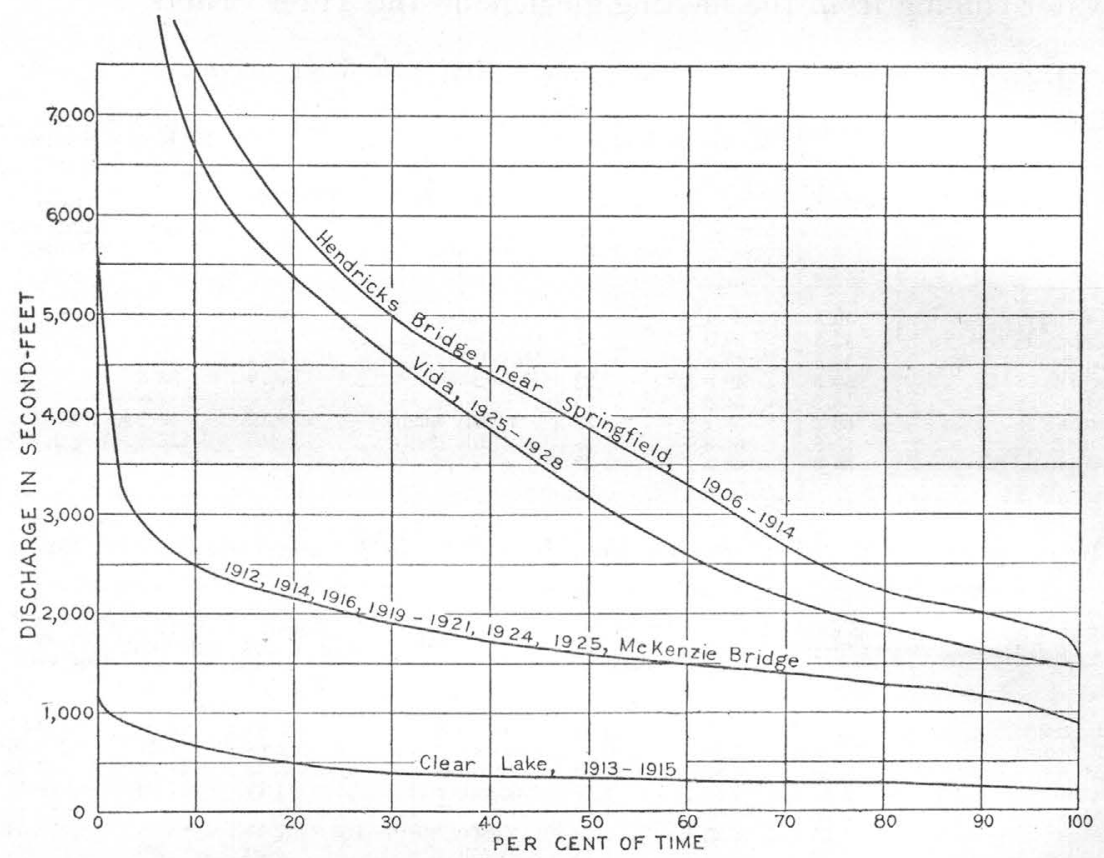

FIGURE 1.-Curves showing relation of discharge in McKenzie River Basin, Oreg., to per cent of time

Olallie Creek are available, and some short summer records were collected in 1926 on Horse Creek and Lost Creek, and in 1927 on the South Fork of the MeKenzie River.

The minimum recorded discharge at McKenzie Bridge was 890 second-feet in October, 1924. The minimum daily discharge for the year ending September 30, 1926, was 934 second-feet in September. In the years of record prior to 1924 the minimum discharge was 924 second-feet in October and November, 1915. The minimum discharge in August and September, 1926, at Vida was 1,430 second-feet, as compared with a minimum of 1,420 second-feet in September, 1914, at Hendricks Bridge. The flow in 1926 was in general the lowest 
of record in western Oregon, and yet the minimum flow of the McKenzie River was not as low as would be expected by comparison with other streams. The minimum flow of the Umpqua River at Elkton was 1,040 second-feet in September, 1914, and 670 second-feet in September, 1926. The McKenzie River, therefore, ranks close to the Deschutes and Klamath Rivers in having a well-sustained lowwater flow-a valuable asset in the utilization of water power. The mean annual discharge at McKenzie Bridge for the year ending September 30, 1924, was 1,540 second-feet, as compared with 1,570 second-feet for the year ending September 30, 1920. It seems probable that the glaciers on the Three Sisters supplied enough additional water during the hot, dry seasons of 1924 and 1926 to offset the deficiency in stream flow caused by low precipitation.

In spite of the well-sustained low-water flow the discharge of the lower McKenzie varies considerably from year to year, depending on the rainfall. For this reason it is necessary to make some allowance in the Q50 and Q90 discharge for the period covered by the record. Thus the Q90 discharge at Hendricks Bridge for the years 1906 to 1914 was 2,010 second-feet, while the Q90 flow at Vida, a short distance upstream, with no large tributaries entering between, for the years 1925 to 1928 was 1,650 second-feet. In 1906 to 1914 the annual precipitation was above the average, whereas in 1926 the precipitation was the lowest of record. The Q90 discharge for 1925, 1927, and 1928 at Vida was 1,800 second-feet. This is probably a fair estimate of the Q90 flow for a long period, but it has been reduced to 1,750 secondfeet in estimating potential power at sites in the vicinity of Vida. The Q50 discharge for 1925, 1927, and 1928 at Vida was 3,400 secondfeet as compared with 3,150 second-feet for the four years 1925 to 1928.

The Q90 discharge at Hendricks Bridge has been arbitrarily reduced from 2,010 second-feet for the period of record to 1,800 second-feet, which seems the more probable average for a long period and agrees with the estimate of the flow at Vida. The Q50 discharges at Vida and Hendricks Bridge agree fairly well, and the figures obtained from the records available have been retained.

Records on Horse Creek at the bridge 3 miles above the mouth for July, August, and September, 1926, indicate a Q90 discharge of 250 second-feet during that year of low flow. The flow of Separation Creek, tributary to Horse Creek, was 100 second-feet greater on July 25, 1927, in a wet year, than on September 9, 1926. On the basis of these short records, the Q90 flow of Horse Creek at the bridge has been estimated at 280 second-feet.

Records are available on Lost Creek near the mouth for the months of July to November, 1926. These records indicate a Q90 discharge for that very dry season of 173 second-feet, but on the basis of the 
records at.McKenzie Bridge the Q90 flow of Lost Creek has been estimated at 225 second-feet and the Q50 flow at 300 second-feet.

A number of discharge measurements were obtained on the South Fork of the McKenzie River during 1926 and 1927 which indicate a Q90 flow below the East Fork of 195 second-feet in 1926 and 245 second-feet in 1927, or, roughly, a mean of 220 second-feet.

\section{Gaging stations maintained on McKenzie River}

Outlet of Clear Lake June, 1912, to July, 1915.

Hendricks Bridge, in sec. 32, T. 17 S., R. 1 W. September, 1905, to March, 1915. Near Springfield. August and September, 1926.

McKenzie Bridge October, 1910, to September, 1914; April, 1915, to September, 1916; April to December, 1917; March, 1918, to October, 1921; May to December, 1922; April, 1923, to December, 1925; May, 1926, to date.

Above Vida, in NE. $1 / 4$ sec. 5, T. 17 S., R. 3 E_- October, 1924, to date.

The records of daily discharge obtained at these stations up to 1923 are published in United States Geological Survey Water-Supply Papers 178, 214, 252, 272, 292, 312, 332, 362, 394, 414, 444, 464, 484, 514, 534, 554, 574, and 594. Water-Supply Paper 370 contains all records to and including 1910. Bulletins 4 and 7 of the State engineer of Oregon, compiled in cooperation with the United States Geological Survey and entitled "Water resources of the State of Oregon," contain monthly summaries of discharge data through 1924.

Monthly discharge of Horse Creek at bridge 3 miles above the mouth in 1926

\begin{tabular}{|c|c|c|c|c|c|}
\hline & \multirow{2}{*}{. } & \multicolumn{3}{|c|}{ Discharge in second-feet } & \multirow{2}{*}{$\begin{array}{c}\text { Run-off in } \\
\text { acre-feet }\end{array}$} \\
\hline & & Maximum & Minimum & Mean & \\
\hline $\begin{array}{l}\text { June } 25-30 \\
\text { July } \\
\text { August } \\
\text { September }\end{array}$ & & $\begin{array}{l}304 \\
288 \\
253 \\
383\end{array}$ & $\begin{array}{l}300 \\
256 \\
240 \\
235\end{array}$ & $\begin{array}{l}302 \\
273 \\
250 \\
281\end{array}$ & $\begin{array}{r}3,600 \\
16,800 \\
15,400 \\
16,700\end{array}$ \\
\hline
\end{tabular}

Monthly discharge of Lost Creek at bridge near the mouth in 1926

\begin{tabular}{|c|c|c|c|c|}
\hline \multirow{2}{*}{ Month } & \multicolumn{3}{|c|}{ Discharge in second-feet } & \multirow{2}{*}{$\begin{array}{c}\text { Run-off in } \\
\text { acre-feet }\end{array}$} \\
\hline & Maximum & Minimum & Mean & \\
\hline 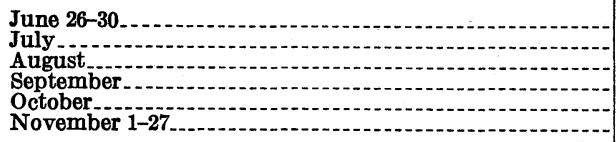 & $\begin{array}{l}235 \\
238 \\
214 \\
199 \\
193 \\
257\end{array}$ & $\begin{array}{l}227 \\
204 \\
186 \\
163 \\
163 \\
170\end{array}$ & $\begin{array}{l}231 \\
226 \\
200 \\
180 \\
171 \\
200\end{array}$ & $\begin{array}{r}2,290 \\
13,900 \\
12,300 \\
10,700 \\
10,500 \\
10,700\end{array}$ \\
\hline
\end{tabular}


WATER-POWER RESOURCES OF MCKENZIE RIVER, OREGON 101

Miscellaneous discharge measurements in the McKenzie River Basin

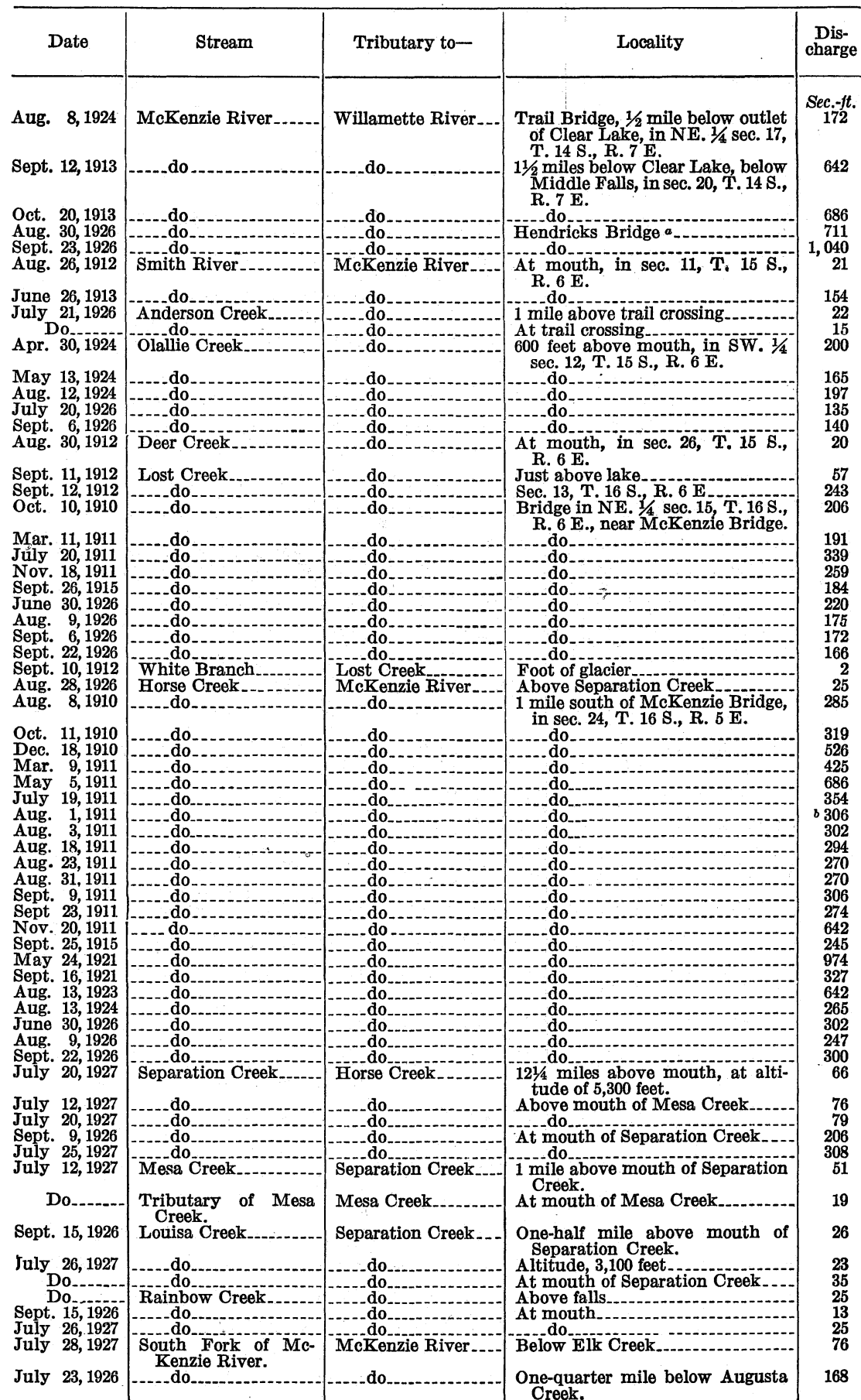

a Does not include diversion to Eugene power plant.

$b$ Discharge estimated from gage reading. 
Miscellaneous discharge measurements in the McKenzie River Basin-Continued

\begin{tabular}{|c|c|c|c|c|}
\hline Date & Stream & Tributary to- & Locality & $\begin{array}{l}\text { Dis- } \\
\text { charge }\end{array}$ \\
\hline June 16,1926 & $\begin{array}{l}\text { South Fork of Mc- } \\
\text { Kenzie River. }\end{array}$ & McKenzie Ri & Above East For & $\underset{228}{\text { Sec. ft. }}$ \\
\hline $\begin{array}{l}\text { Aug. } 8,1926 \\
\text { Sept. 22, } 1926\end{array}$ & - do do no & -....do. do & -..do.. & $\begin{array}{l}185 \\
225\end{array}$ \\
\hline July 27,1927 & - do & - do & - & 253 \\
\hline Aug. 20, 1927 & -...-do... & -....do. & ......do.......... & 246 \\
\hline $\begin{array}{l}\text { Sept. } 15,1927 \\
\text { Sept. } 3,1912\end{array}$ & - do do & \begin{tabular}{c}
$----d o$ \\
\hdashline.$--d o$
\end{tabular} & Sec. 5, T. 17 S. R., 5 E. & $\begin{array}{l}298 \\
114\end{array}$ \\
\hline July 29, 1927 & Roaring River & $\ldots . .$. do & At mouth - & 126 \\
\hline June 29,1926 & $\begin{array}{l}\text { South Fork of Mc- } \\
\text { Kenzie River. }\end{array}$ & - do & Near mouth.. & 219 \\
\hline June 16,1923 & $\begin{array}{l}\text { East Fork of South } \\
\text { Fork. }\end{array}$ & $\ldots$ do & At mouth. & 10.6 \\
\hline $\begin{array}{l}\text { Aug. } \begin{array}{r}8,1926 \\
\text { Sept. 22, } 1926\end{array}\end{array}$ & do & do & ...do do & 1.7 \\
\hline une 17,1926 & Blue River & -...do do & _..._do do & 50 \\
\hline Aug. 8,1926 & ...do do & $\ldots d$ & $d$ & 16 \\
\hline
\end{tabular}

MAGNITUDE, DURATION, AND FREQUENCY OF FLOODS

The McKenzie River Valley is narrow and wooded, and both the tributaries and the main stream have a considerable fall. The soil of the basin is very porous, and a large part of the precipitation sinks into the ground. All these factors tend to reduce the flood flow, and at points above McKenzie Bridge the flood flows are small. The maximum recorded daily discharge at McKenzie Bridge was 8,600 second-feet in December, 1920. Probably the peak flow was 10,000 second-feet. At the gaging station at Hendricks Bridge, near Springfield, the maximum recorded discharge was 37,900 second-feet in February, 1907. At the time of the floods in the Umpqua River Basin, in November, 1909, the discharge at Hendricks Bridge reached a maximum of 35,400 second-feet.

On the headwaters of the McKenzie the ground is pervious and would absorb a large amount of precipitation, and in the glacial area of the Three Sisters freezing temperatures occur at night during the months when flood discharges can be expected. The maximum recorded flow for 24 hours at Hendricks Bridge was 37,900 second-feet and at McKenzie Bridge 8,600 second-feet. Probably at Hendricks Bridge the peak flow was several thousand second-feet higher than the 24-hour flow, but at McKenzie Bridge the peak was probably not much greater than the 24-hour flow.

\section{PRIOR WATER RIGHTS}

Diversions for irrigation are not sufficient to have an appreciable effect on the flow of the McKenzie River. The city of Eugene diverts about 1,000 second-feet in the SE. $1 / 4$ sec. 23 , T. 17 S., R. 1 W., for its municipal power plant No. 1 (12ND 14) and this water is returned to the river in sec. 25, T. 17 S., R. 2 W. The city probably has a right to the entire flow of the river through this section. The Eugene municipal power plant No. 2 (12ND 12), which is being constructed farther upstream, near Leaburg, will divert water in sec. 31, T. 16 S., R. 2 E., and return it to the river in sec. 9, T. 17 S., R. 1 E. 
U. S. GEOLOGICAL SURVEY

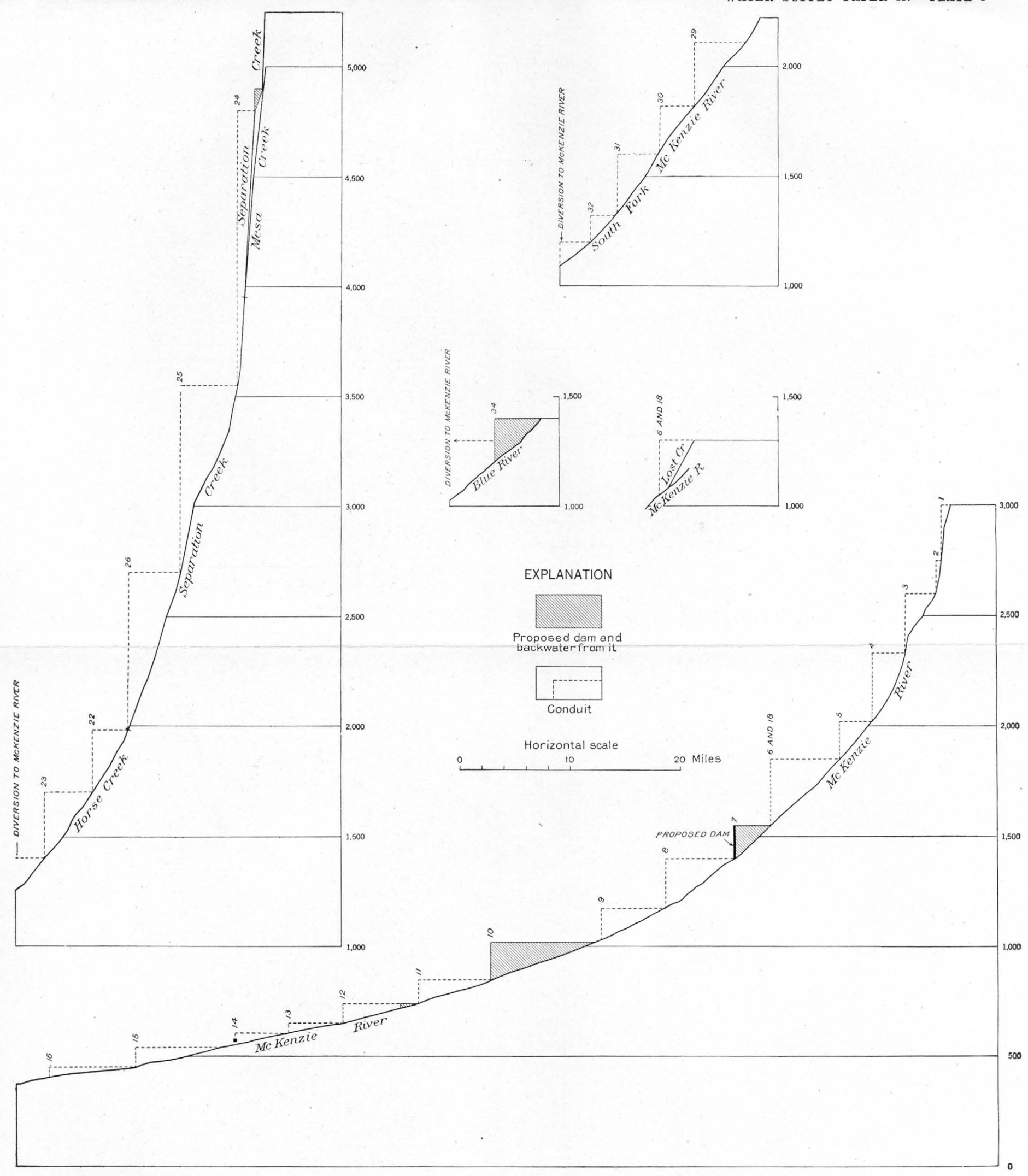

PROFILE OF THE MCKENZIE RIVER, OREG., AND ITS TRIBUTARIES, FROM CLEAR LAKE TO WILLAMETTE RIVER

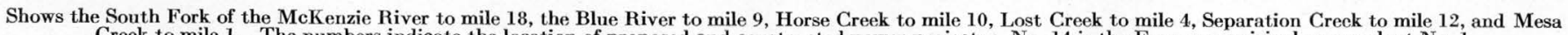
Creek to mile 1. The numbers indicate the location of proposed and constructed power projects. No. 14 is the Eugene municipal power plant No. 1 . 


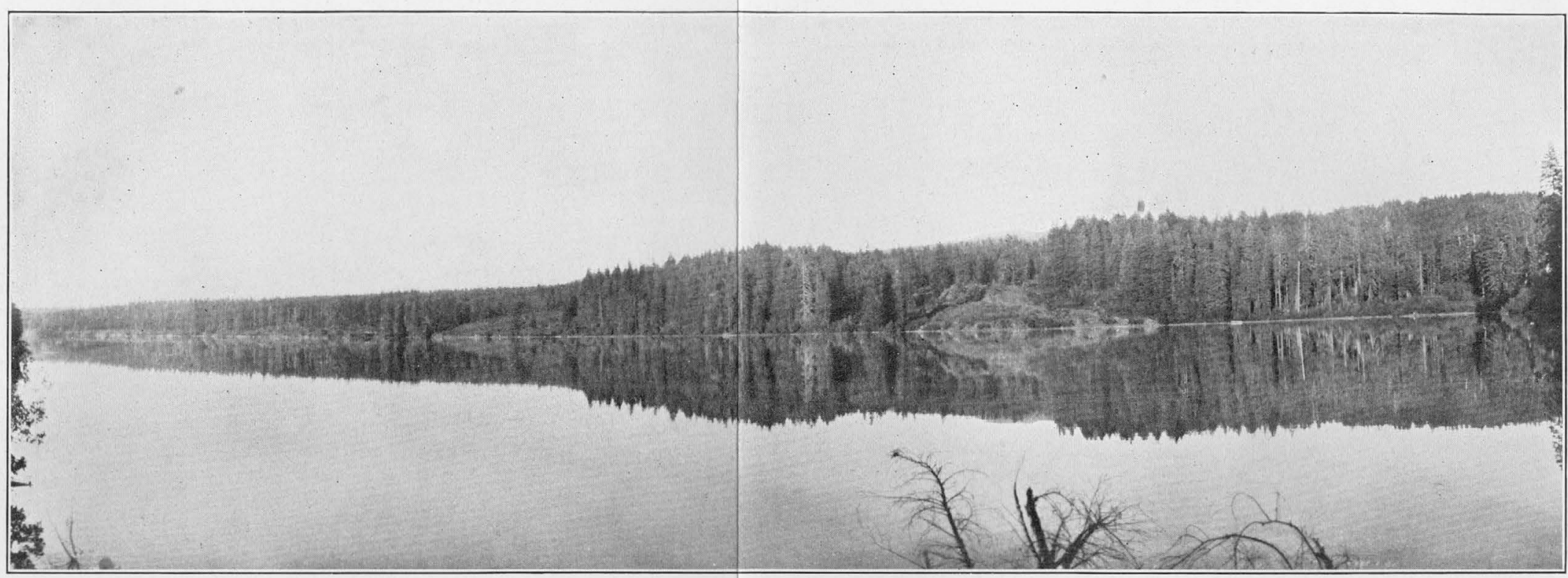

A. CLEAR LAKE, McKENZIE RIVER BASIN, FROM OUTLET

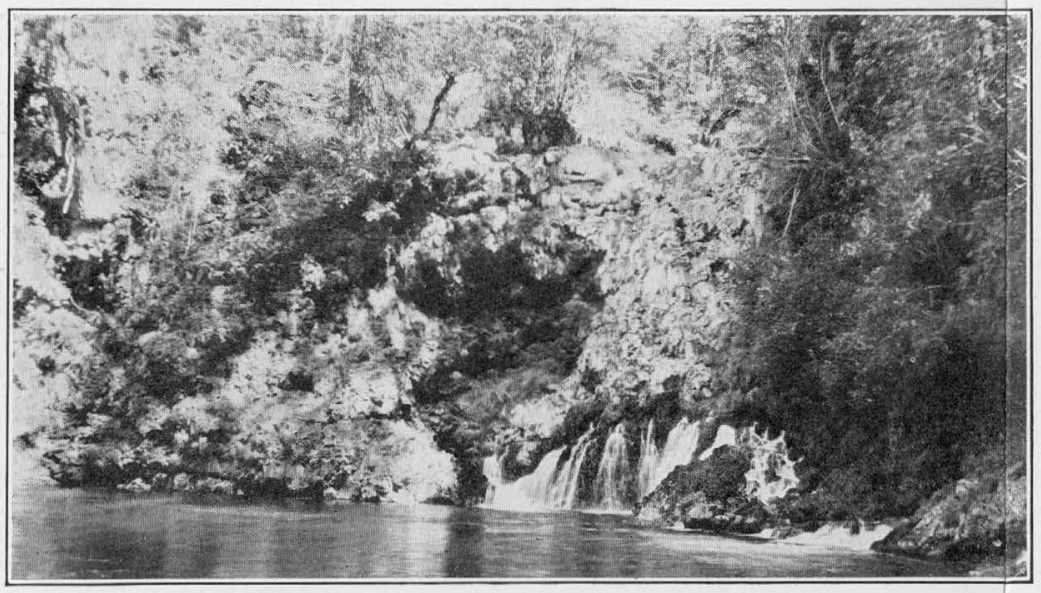

B. POOL BELOW LOWER FALLS OF THE MCKENZIE RIVER Dry falls in background, with springs issuing from their base.

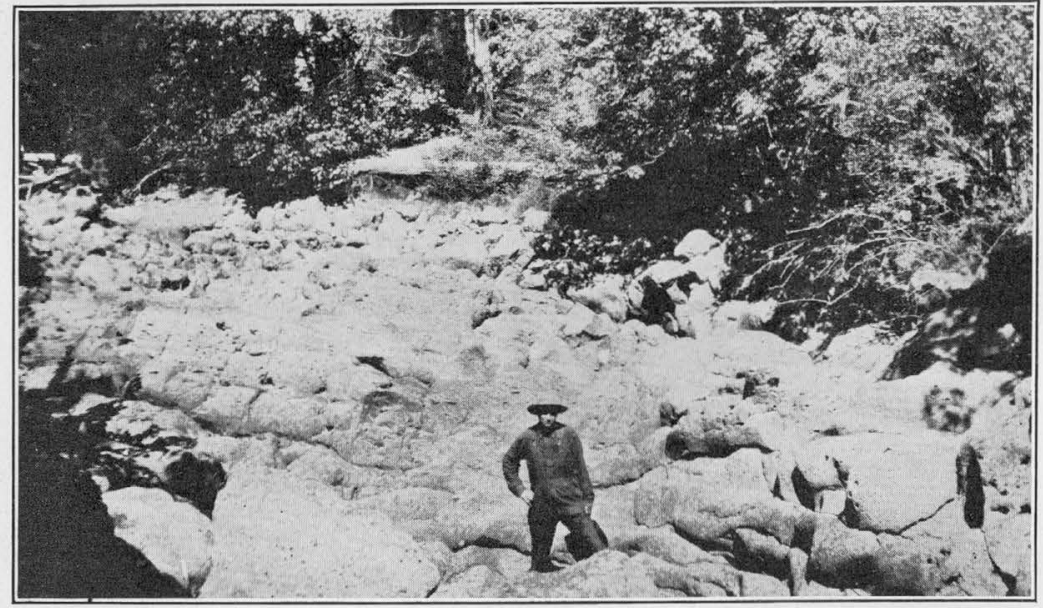

C. DRY BED OF THE MCKENZIE RIVER A QUARTER OF A MILE ABOVE LOWER FALLS 


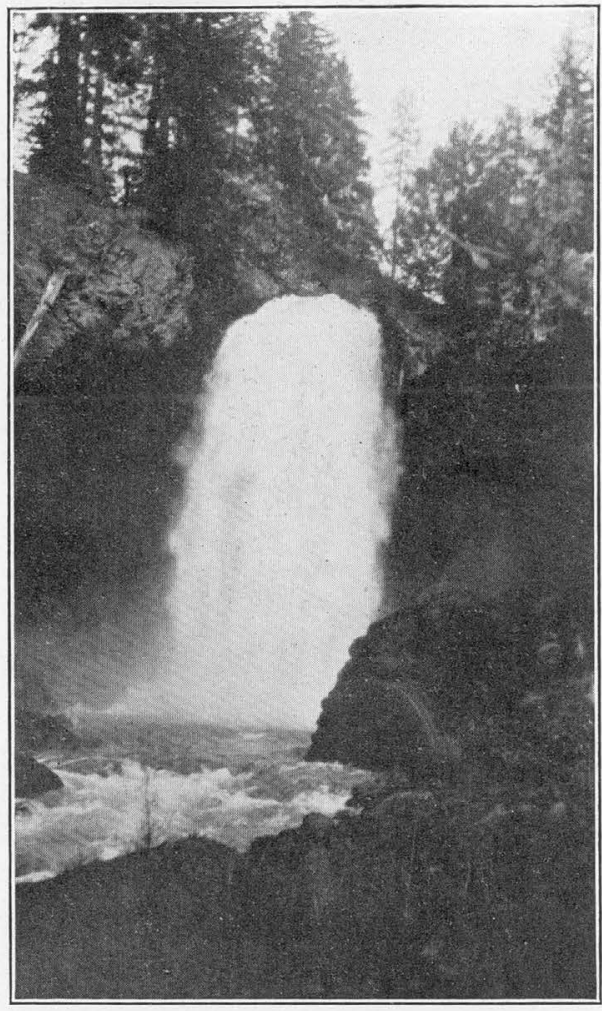

A. UPPER FALLS, MCKENZIE RIVER

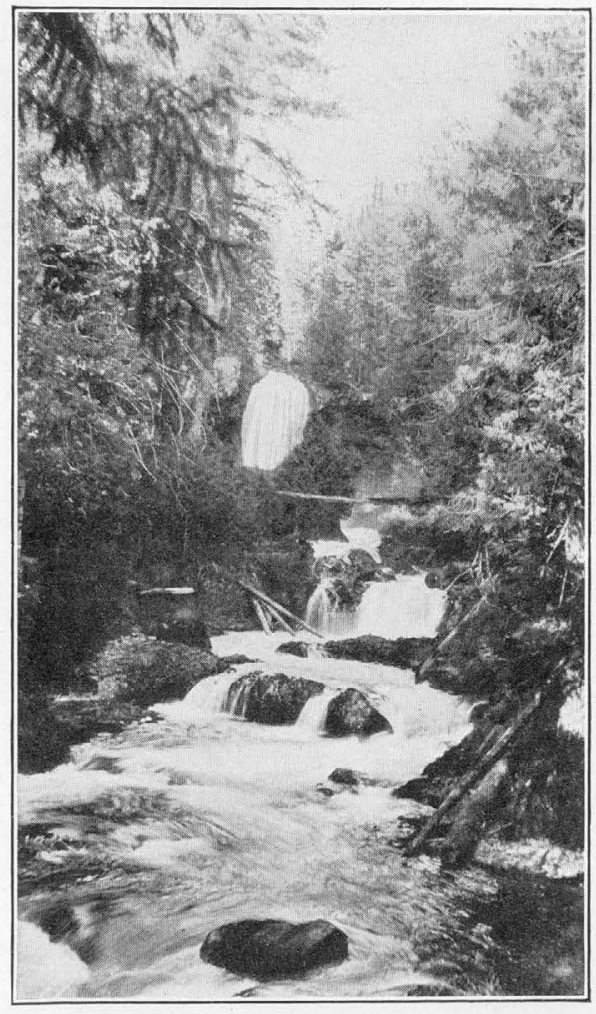

B. CASCADES BELOW UPPER FALLS Falls in background. 


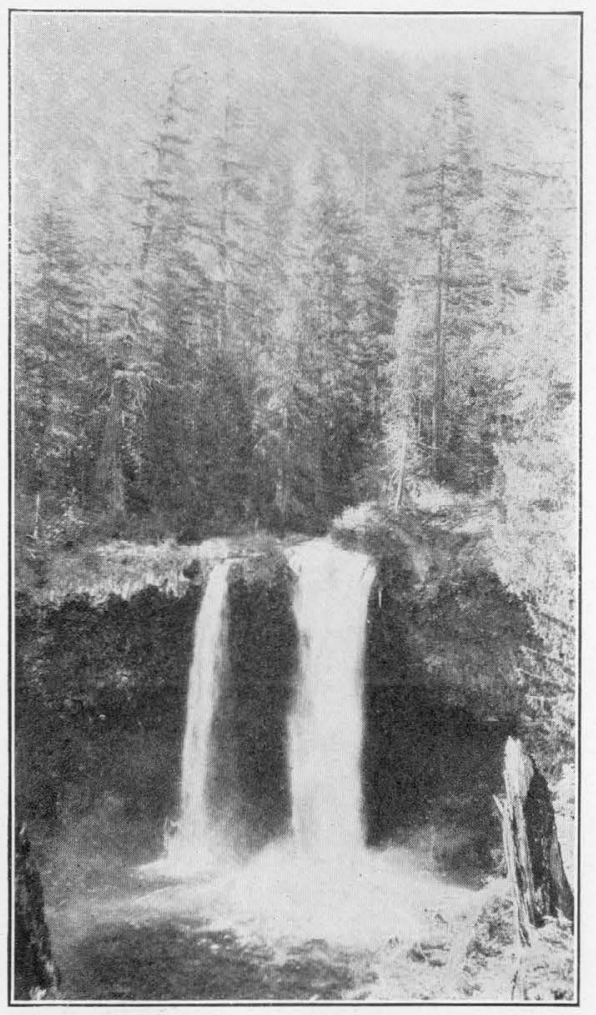

A. MIDDLE FALLS, MCKENZIE RIVER

All this water sinks into the ground a short distance downstream and rises in a pool below Lower Falls.

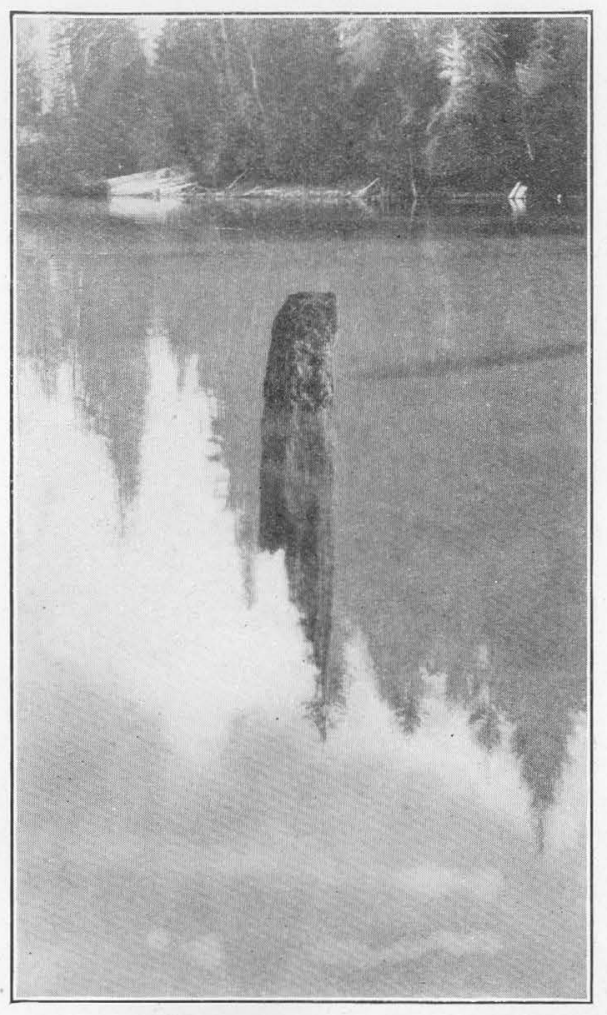

B. ANCIENT TREE TRUNK PRESERVED IN THE WATER OF CLEAR LAKE

The tree grew before the lava flow dammed the valley and formed Clear Lake. 
These plants are not provided with storage. The 20-foot diversion dam at the upper site will provide some pondage, and at the lower plant some extra water can be obtained for a short period by drawing down the canal. It is possible that the total pondage would amount to half of the daily discharge during the low-water months, permitting the plants to use all the water when operating on a 50 per cent load. factor. The city of Eugene also diverts water from the McKenzie River for municipal purposes, but this diversion is so near the mouth that it will not interfere with water-power development.

\section{RECREATIONAL USE}

The McKenzie River is paralleled by a highway from its mouth to Lost Creek and has been extensively advertised by the city of Eugene as a recreational area. Hotels are located at natural hot springs and at other points in the valley, and there are a number of summer homes along the river. The city plans to allow 300 secondfeet to flow continuously in the river channel to preserve the natural charm and for fishing. Clear Lake also provides good fishing and boating, and there are ideal camping sites along its shores. (See pl. $4, A$.)

Development of the power resources of the river under proper safeguards need not interfere with a large recreational use of the river as well as the lake. The Upper Falls, below Clear Lake, present a beautiful scenic effect (see pl. 5), and it seems fitting that they should not be marred by the development of power but be preserved in their natural state. However, in the opinion of the writers the Middle and Lower Falls are less beautiful-in fact, the Lower Falls are dry for a large part of the year, because the water flows beneath the surface. (See pls. $4, B, C$, and 6, $A$.) By diversion farther upstream the head at the Lower Falls could be used for power, or the drop at both the Middle and Lower Falls might well be so used.

\section{RIVER CONTROL}

The flow of the McKenzie River is very effectively controlled by ground storage in the area above McKenzie Bridge and by the snow and glaciers on the Three Sisters. The effect of this storage is evident in the well-sustained flow during the summer at McKenzie Bridge and Vida.

There are no large reservoir sites in the basin. The lakes are of little value for storage. Clear Lake is caused.by a lava flow which dammed the old river valley, and at all stages there is a considerable leakage from the lake through or around this lava dam. Horse Lake, at the head of Horse Creek, is small and has only a few square miles of drainage area. Considerable storage could be developed by constructing dams on the main stream, the principal obstacle being the 
cost of the land and improvements that would be flooded. A small amount of storage could be obtained on the South Fork of the McKenzie River, but it would be expensive because of the steep slope of the valley. A reservoir could be constructed on the Blue River, but it would require two dams of considerable length, and the capacity would not be great; with a very large demand for power storage at this site might prove feasible. On account of the well-sustained flow due to ground storage, however, reservoirs are not so necessary as on some other rivers, and, because of this fact and the large uniform fall, power will be developed mostly by low dams and conduits. Some storage can be obtained on the main stream by drawing down the head above proposed dams, but the net gain in power will not be very great.

In the main, power developed on the McKenzie River will be dependent on the natural flow and will require interconnection with other water-power systems or steam stations to obtain the most effective and most economical results.

\section{STORAGE SITES}

There are no developed storage sites in the McKenzie River Basin. No reservoir sites capable of development for storage only were found on the McKenzie River itself. Some storage can be developed by drawing down the head at the Paradise site (12ND 7) and the Eugene municipal site No. 3 (12ND 10), on the McKenzie River, and at the Mesa Creek site (12ND 24), on Separation Creek, but as it is assumed that these sites are of value primarily for power, the storage is discussed in connection with the power. (See pp. 111, 113, 119.) The only site proposed to be developed primarily for storage is on the Blue River (12ND 34). In estimating the potential power with storage it was assumed that regulation will be provided to give a uniform flow. This plan would give the best results for the river as a whole, but if a single plant were concerned the storage would probably be used to give a uniform power output. The capacity of the proposed storage sites is given in the table below. Further description is given under the individual sites.

Capacity of reservoir sites in the McKenzie River Basin

\begin{tabular}{|c|c|c|c|c|c|}
\hline \multirow{3}{*}{ Name } & \multirow{3}{*}{ Stream } & \multirow{3}{*}{ Location of dam } & \multicolumn{3}{|c|}{ Net capacity } \\
\hline & & & \multirow{2}{*}{ Acre-feet } & \multicolumn{2}{|c|}{$\begin{array}{c}\text { Millions of } \\
\text { kilowatt-hours }\end{array}$} \\
\hline & & & & $\underset{\text { site }}{\text { At }}$ & $\begin{array}{l}\text { At all } \\
\text { sites }\end{array}$ \\
\hline \multirow{4}{*}{ 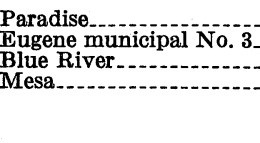 } & \multirow{4}{*}{$\begin{array}{l}\text { McKenzie River... } \\
\text { Blue River } \\
\text { Separation Creek }\end{array}$} & \multirow{4}{*}{$\begin{array}{l}\text { Sec. 18, T. } 16 \text { S., R. } 6 \text { E } \\
\text { Sec. 32, T. } 16 \text { S., R. } 3 \text { E } \\
\text { Sec. 14, T. } 16 \text { S., R. } 4 \text { E } \\
\text { Above Mesa Creek. }\end{array}$} & 60,000 & \multirow{4}{*}{$\begin{array}{l}-31 / 2 \\
-1 \\
+51 / 2 \\
+4\end{array}$} & +36 \\
\hline & & & 59,000 & & +35 \\
\hline & & & 5,350 & & \\
\hline & & & 214,350 & & +114 \\
\hline
\end{tabular}




\section{CLEAR IAKE RESERVOIR SITE}

The location of Clear Lake at the head of the McKenzie suggests that it might be a reservoir site, but owing to the nature of the rock formations at the outlet it is extremely doubtful if the lake could be made to hold any large amount of water, and therefore it has not been considered in this report a potential reservoir.

Clear Lake (see pl. 4, A) lies in secs. 5 and 8, T. 14 S., R. 7 E. It is about one-third of a mile wide and $1 \frac{1}{4}$ miles long and occupies a narrow valley. The west shore is a relatively steep soil-covered slope supporting a growth of large firs and pines. The east shore rises gently, and much of it consists of rough, clinkery aa lava, in places nearly barren of vegetation. About 200 feet from the northeast shore of the lake, Great Spring issues quietly in a pool of green water with a temperature of $39^{\circ}$. It discharges about 20 second-feet of water, which flows westward into the lake.

In September, 1926, Ikinick Creek was discharging less than 1 second-foot of water into the northwest corner of the lake. During wet weather Fish Lake becomes the head of the McKenzie River and overflows into Clear Lake, but in September, 1926, it was practically dry and no water was flowing in its outlet channel. A measurement at the outlet of Clear Lake on August 8, 1924, showed a discharge of 172 second-feet, and doubtless the inflow at that time did not exceed 25 second-feet, so that 147 second-feet is left to be accounted for. This water rises in the bottom of the lake.

The dam site at Clear Lake is in the NE. $1 / 4$ NE. $1 / 4$ sec. 17 , near the outlet, and its west abutment is composed of loose blocks of basalt of an aa lava flow. Pine trees 3 feet in diameter grow on the surface of the lava flow, indicating that it is fairly ancient. This lava flow dammed the McKenzie River, producing the lake. A submerged upright forest is visible in the shallow northern part of the lake. This forest was growing on the river bank at the time the lava dammed the valley, and the trees, being submerged, have been preserved. (See pl.6, B.)

An investigation of the southeast shore of the lake revealed a curious condition. Attention was attracted to this part of the shore by great quantities of driftwood. Because the wind does not usually blow from the northwest at this place, it was concluded that the driftwood was carried there by a current. A muddy channel 30 feet wide filled with driftwood was found leading away from the lake shore at this place. It is evident that during wet weather this entire channel is submerged. In the first 200 feet the channel is filled with numerous small springs, which had a temperature of $40^{\circ} \mathrm{F}$. and a combined discharge of about 8 second-feet. About 300 feet from the shore the channel ends abruptly against the end of the aa lava that formed the dam to the lake. At this place the entire flow of the springs cascades into a sinkhole partly filled with driftwood. The hole is about 10 feet in diameter and 3 feet deep, with a distinct funnel shape. Numerous holes of similar shape filled with water occur near by. These holes apparently receive water during high stages of the lake.

On September 12, 1913, according to the daily discharge records, ${ }^{1}$ the flow at the outlet of Clear Lake was 319 second-feet. On the same day a measurement of the McKenzie River 1/1/2 miles below Clear Lake and below the Middle Falls, in sec. 20, T. 14 S., R. 7 E., showed a flow of 642 second-feet. No surface streams enter the river between these two points, hence the net gain in $1 \frac{1}{2}$ miles of the McKenzie channel on this day was 323 second-feet. Only a very small part of this inflow can be seen as springs entering from the bank of the river. The remainder must therefore issue as springs from the river bed. Most of this inflow is believed to be leakage from Clear Lake that finds its way underground through the natural lava dam at its outlet.

1 U. S. Geol. Survey Water-Supply Paper 362, p. 659, 1915. 
It is evident that a dam at the proposed site would fail to impound the water, because of leakage through the lava flows at the south end of the lake. The history of many other lakes in Oregon formed by lava flows shows that it is impossihle to store water in them.

\section{FOLEY RIDGE RESERVOIR SITE}

A dam 150 feet high at mile 69.3, at the point where the Foley Ridge Trail intercepts the McKenzie Highway, would create a reservoir with a capacity of 35,000 acre-feet, of which 27,000 acre-feet would be in the upper 60 feet. An earth dam at this site 150 feet high would contain about $3,000,000$ cubic yards of material. The water from the reservoir could be dropped through penstocks to a power house on the north side of the McKenzie River and be discharged into a canal leading to a power house at the mouth of the Blue River. If the upper 60 feet were used for storage, the stored water would generate 24,000,000 kilowatt-hours at all proposed sites on the McKenzie River, but if the period of drawdown were to cover four months the loss of power due to loss of head would

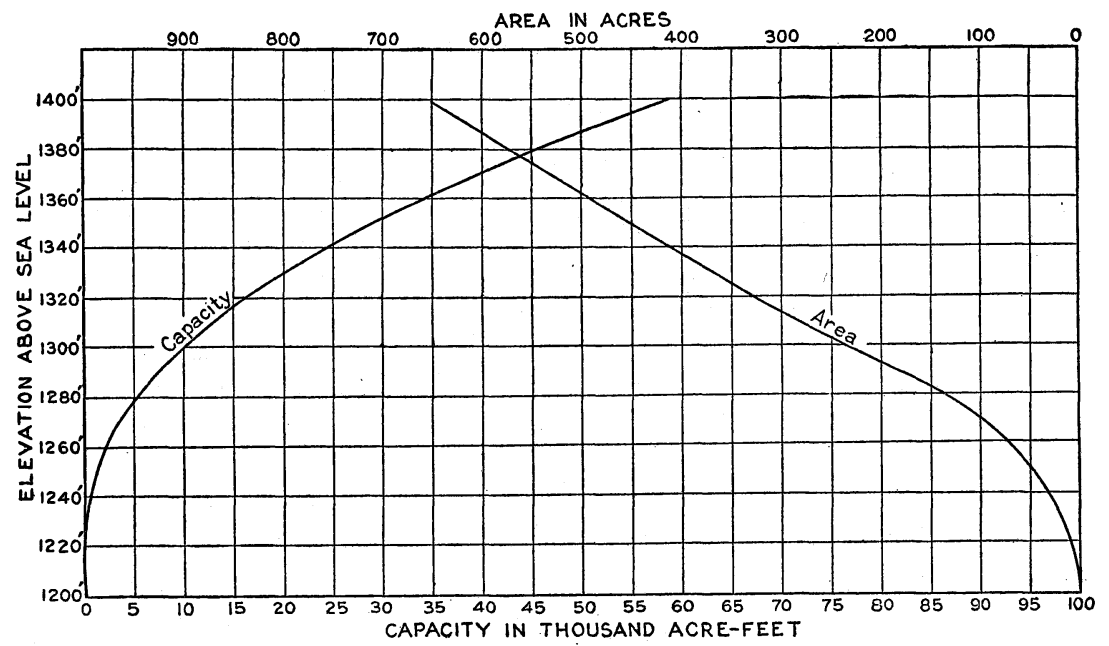

FIguRE 2.-Area and capacity curves, Blue River reservoir site, McKenzie River Basin

amount to $5,000,000$ kilowatt-hours, leaving a net development of 19,000,000 kilowatt-hours. The cost of developing the head by a dam would be much greater than by a tunnel, such as that proposed for the Belknap project (12ND 6). In addition to the greater cost of a dam, which might be justified, there is serious question as to whether the geologic conditions are such that the reservoir would hold water. There would also be much opposition to the flooding of Belknap Hot Springs. In view of all these adverse conditions, this site is considered impracticable.

\section{BLUE RIVER RESERVOIR SITE (12ND 34)}

A dam 200 feet high on the Blue River in the NW. 1/4 sec. 14, T. 16 S., R. 4 E., would create a reservoir with a capacity of 59,000 acre-feet (see fig. 2) of which 49,000 acre-feet would be in the upper 100 feet. Bedrock, apparently andesite, is exposed in the bed of the river. About 15 feet of gravel would have to be cleaned off the right bank for a distance of $\mathbf{4 0 0}$ feet, and also from the right abutment. The left abutment is a rock ledge and would require little excavation. 
There are two possible sites very much alike, about a quarter of a mile apart. A dam at the upper site would be 100 feet longer but 10 feet lower. A dam at either site would be expensive. An auxiliary dam 100 feet high and 2,000 feet long would be required to close the gap between the Blue River and the McKenzie River. Water from this site would be carried through the gap to the McKenzie River at mile 57, where it could be used at the Blue River power site. (See p. 123.)

The reservoir would have an area of 700 acres, but as all the land is of very poor character, the principal cost would be for the dams. The water stored above the 1,300-foot level could be used through a total head of 925 feet on the McKenzie River, and at an efficiency of 70 per cent it would generate $33,000,000$ kilowatt-hours of energy. The water stored below the 1,300-foot level could be used through a total head of 600 feet and would generate 4,000,000 kilowatt-hours. The loss of power due to loss of head at this site would be negligible, as the Blue River has a very low flow in summer.

The drainage area of the Blue River above the dam site amounts to 40 square miles, and as the mean annual run-off is estimated at 106,000 acre-feet, there would be no trouble in filling the reservoir even in a dry year. During the summer the run-off drops to about 20 second-feet, so that the reservoir could be completely emptied, thus destroying the head, and yet there would be little loss of power at the dam site due to not using this small natural flow.

\section{WATER POWER}

The annual precipitation on the headwaters of the McKenzie River averages about 100 inches. Most of this occurs during nine months of the year, but the porous volcanic soil provides a large underground regulating reservoir, so that the river has a well-sustained flow throughout the summer. Even in such years as 1924 and 1926 , which were the driest of record in western Oregon, the flow of the McKenzie River was not affected to nearly so great a degree as that of other streams in the same general locality. The river has a fall of 2,630 feet in 86 miles-1,650 feet in the 21 miles from Clear Lake to McKenzie Bridge and 980 feet in the 65 miles from McKenzie Bridge to the mouth.

From the mouth of Clear Lake to Belknap Springs the river flows in a canyon; in this section power will be developed by means of low dams and conduits, partly because of the steep slope and partly because of probable leakage if high dams were built. From Belknap Springs to Martin Rapids the river valley is rather narrow but still so wide that high dams would be long and expensive except possibly at two sites, which are discussed elsewhere. Below Martin Rapidis development will be effected by low dams and open-cut canals, as in the developed project of the city of Eugene.

Separation Creek, tributary to Horse Creek, has a well-sustained flow even at 5,000 feet above sea level, and because of its rapid fall the cost of developing the power should not be great. At present the creek, especially the headwater portion, is very inaccessible, but roads to reach it will probably be built in the course of a few years. 
Horse Creek has a good flow of water below the mouth of Separation Creek, but above that point the discharge drops as low as 25 second-feet in a dry summer.

The flow of the South Fork of the McKenzie River amounts to at least 150 second-feet at the mouth of the Roaring River, even in a dry year, and power development on this stream should be financially feasible, as the fall is between 50 and 100 feet to the mile.

\section{DEVELOPED POWER}

\section{EUGENE MUNICIPAL POWER PLANT NO. 1 (12ND 14)}

Water for Eugene municipal power plant No. 1 (see pls. 8, $A$, and 9, $B$ ) is diverted from the river into a large open canal in the SE. $1 / 4$ sec. $23, \mathrm{~T}$. $17 \mathrm{~S}$., R. 1 W., and carried about 4 miles to a plant in the NW. 1/4 sec. 29, T. 17 S., R. $1 \mathrm{~W}$. The net head is about 45 feet. The hydraulic machinery has a capacity of 4,300 horsepower, consisting of two turbines rated at 1,200 horsepower each and one rated at 1,900 horsepower. The three generators have a rated capacity of 3,285 kilovolt-amperes. There is no auxiliary power, but the city purchases power from the Mountain States Power Co. Water from the plant is discharged into a short canal, from which it flows down an old channel, reaching the river again at the mouth of Camp Creek, in sec. 25, T. 17 S., R. 2 W. A second plant (12ND 12) is under construction near Leaburg.

Potential power at site 12ND 14

[Gross head, 55 feet]

\begin{tabular}{|c|c|c|c|c|}
\hline \multirow[t]{2}{*}{. } & \multicolumn{2}{|c|}{ Flow in second-feet } & \multicolumn{2}{|c|}{ Horsepower } \\
\hline & $\begin{array}{c}90 \text { per cent } \\
\text { of time }\end{array}$ & $\begin{array}{c}50 \text { per cent } \\
\text { of time }\end{array}$ & $\begin{array}{c}90 \text { per cent } \\
\text { of time }\end{array}$ & $\begin{array}{c}50 \text { per cent } \\
\text { of time }\end{array}$ \\
\hline $\begin{array}{l}\text { Natural flow } \\
\text { With storage at Eugene municipal site No. } \\
\text { With storage at all proposed sites. }\end{array}$ & $\begin{array}{l}1,790 \\
2,220 \\
2,650\end{array}$ & $\begin{array}{l}3,550 \\
3,550 \\
3,550\end{array}$ & $\begin{array}{r}7,880 \\
9,770 \\
11,600\end{array}$ & $\begin{array}{l}15,600 \\
15,600 \\
15,600\end{array}$ \\
\hline
\end{tabular}

\section{UNDEVELOPED POWER}

In outlining power schemes and in estimating the potential power of the sites described below all the fall and stream flow has been included. Because of the recreational use of the area, however, it will probably be necessary to allow some water to flow continuously in the channel of the river, and possibly some stretches will never be developed because of their scenic value. Owing to the steep slope of the stream bed in the upper section and the wide valley in the lower section, most of the development will be effected by means of low dams and conduits.

\section{UPPER FAIIS POWER SITE (12ND 1)}

The Upper Falls site is considered as a single unit because it may be desirable to preserve these falls (see pl. 5) for their scenic value rather than to use them for the development of power. Water would be diverted at the outlet of Clear Lake and carried along the left bank of the McKenzie River in a lined conduit 
or pipe for about a mile, to a point between the Upper and Middle Falls, where a head of 250 feet would be obtained. Clear Lake would furnish storage to take care of any daily fluctuations in load, and plants at this site and those immediately below it might become valuable peak-load plants if the power were used for city lighting. As the country is rough and construction of open conduits would be expensive, it is probable that a pipe line would be used. The natural Q90 flow at this site is 242 second-feet, and the Q50 flow is 340 second-feet. With a gross head of 250 feet 4,840 horsepower could be developed for 90 per cent of the time and 6,800 horsepower for 50 per cent of the time.

\section{MIDDLE FALLS POWER SITE (12ND 2)}

The Middle Falls project was selected in order to allow the Upper Falls to be preserved for their scenic value, if desired, and at the same time to develop the power of the remainder of the river. The intake would be a short distance below the Upper Falls, at the point considered for the power house of that site (12ND 1). Water would be diverted by a low dam and carried in a lined or closed conduit for less than half a mile to a power house below the Middle Falls, at the 2,600-foot contour crossing, where a head of 150 feet would be obtained. This location of the power house would take advantage of the inflow of underground water, so that the maximum flow in the river would be obtained for diversion for the next project below. The flow below the Middle Falls is considerably greater than at the outlet of Clear Lake, whereas at the Lower Falls the stream is dry in the summer. A view of the Middle Falls is given in Plate 6, $A$.

The Q90 flow for this project is assumed to be 80 second-feet greater and the Q50 flow 100 second-feet greater than at the outlet of Clear Lake. This assumption is based on two measurements made below the Middle Falls in 1913. The first measurement, on September 12, gave 642 second-feet below the Middle Falls, compared with 319 second-feet at the outlet of Clear Lake, showing an inflow of 323 second-feet. A second measurement on October 20 gave 686 second-feet below the Middle Falls and 364 second-feet at the outlet of Clear Lake, showing an inflow of 322 second-feet. The increase of 45 second-feet in discharge at the outlet of Clear Lake seemed to cause no increase in the flow from the springs that supplied the inflow between Clear Lake and the Middle Falls. It is felt that at least part of this increase would enter the river below the Upper Falls and so be available for this project.

The natural Q90 flow at this site is estimated at 322 second-feet, and the Q50 flow at 440 second-feet. With a head of 150 feet, 3,860 horsepower could be developed for 90 per cent of the time and 5,280 horsepower for 50 per cent of the time.

\section{LOWER FAIIS POWER SITE (12ND 3)}

Water for the Lower Falls project would be diverted just below the proposed power house of the Middle Falls project (12ND 2), at the point of maximum lowwater flow in the river. This point has been tentatively set at the 2,600-foot contour crossing.

The discharge at this site on September 12 and October 20, 1913, was 322 second-feet greater than at the outlet of Clear Lake. (See also discussion of site 12ND 2). The flow at the outlet of Clear Lake was 319 second-feet on September 12 and 364 second-feet on October 20, 1913, or nearly the same as the Q50 discharge, which was 340 second-feet for the 3-year period 1913-1915. From these data the Q50 discharge at the Lower Falls site is estimated at 660 second-feet. The Q90 discharge at the outlet of Clear Lake was 242 second-feet for 1913-1915, or about 100 second-feet less than the Q50 discharge. If it is assumed that the inflow between the outlet of the lake and this site would be somewhat more con-

$3030^{\circ}-31-8$ 
stant, as it comes from springs, and that the inflow for 90 per cent of the time was only 82 second-feet less than the inflow for 50 per cent of the time the Q90 flow at this site would be 480 second-feet.

The conduit would be a pipe line about $3 \frac{1}{2}$ miles long, with perhaps some stretches of lined canals. The right bank is an older and more weathered formation than the left bank, which is a recent lava flow, and the conduit would probably follow the right bank. The water from the power house would discharge into the pool just below the Lower Falls. (See pl. 4, B.) With a gross head of 270 feet and a natural Q90 flow of 480 second-feet and a Q50 flow of 660 second-feet, 10,400 horsepower could be developed for 90 per cent of the time and 14,200 horsepower for 50 per cent of the time.

For the construction of the projects here proposed, it would be necessary to extend a road up the McKenzie River from Belknap Springs to Clear Lake, to transport material, but such a road is a natural development and probably will be built by the United States Forest Service before the water power is developed.

\section{SMITH RIVER POWER SITE (12ND 4)}

Water for the Smith River project would be diverted from the McKenzie River just below the power house of the Lower Falls site (12ND 3) and carried by a conduit for 3 miles along the right bank of the river to a power house at the mouth of the Smith River, where a head of $\mathbf{3 1 0}$ feet would be obtained.

Between the Middle Falls and McKenzie Bridge there is an increase of $\mathbf{6 8 0}$ second-feet in the Q90 flow and of 930 second-feet in the Q50 flow. Some of this increase is accounted for by the flow of Horse and Olallie Creeks, but there is still a considerable surplus, which must come largely from springs. It is assumed that the Q90 flow at this site is 50 second-feet greater and the Q50 flow 70 second-feet greater than the flow available for use at site 12ND 3. The natural Q90 flow at this site is $\mathbf{5 3 0}$ second-feet, and the Q50 flow 730 second-feet. With a gross head of 310 feet 13,100 horsepower could be developed for 90 per cent of the time and 18,100 horsepower for 50 per cent of the time.

\section{DEER CREEK POWER SITE (12ND 5)}

Water for the Deer Creek project would be diverted below the power house of site 12ND 4, at the mouth of the Smith River. By carrying the conduit along the left bank of the river both Anderson Creek and Olallie Creek could be diverted and used. The proposed power-house site is just above Deer Creek, at mile 75.6, where a head of 170 feet would be obtained. The discharge for this site would be considerably greater than that for the Smith River site, because numerous spring-fed creeks enter the river just above the proposed intake. Anderson Creek is a surface stream with a low-water flow of 16 to 20 second-feet. Olallie Creek is fed by two springs at about the 2,180-foot contour. Measurements in 1926 showed 135 second-feet on July 20 and 140 second-feet on September 6; this was an extremely dry period. Measurements in 1924, which was also a dry year, showed 200 second-feet on April 30, 165 second-feet on May 13, and 197 second-feet on August 12. It would seem safe to assume a Q90 discharge of 165 second-feet for Olallie Creek. Adding 15 second-feet for Anderson Creek and 110 second-feet for the springs and creeks between the Lower Falls and Smith River sites gives a total $\mathrm{Q} 90$ discharge for this site of 820 second-feet.

There would be no unusual features in the development of this site. The conduit would be about 3 miles long, and for a large part of the way an open lined canal could be used.

The natural Q90 flow at this site is 820 second-feet, and the Q50 flow, estimated from this Q90 discharge and the ratio of Q50 to Q90 at McKenzie Bridge, is 1,120 second-feet. With a gross head of 170 feet 11,100 horsepower could be developed for 90 per cent of the time and 15,200 horsepower for 50 per cent of the time. 

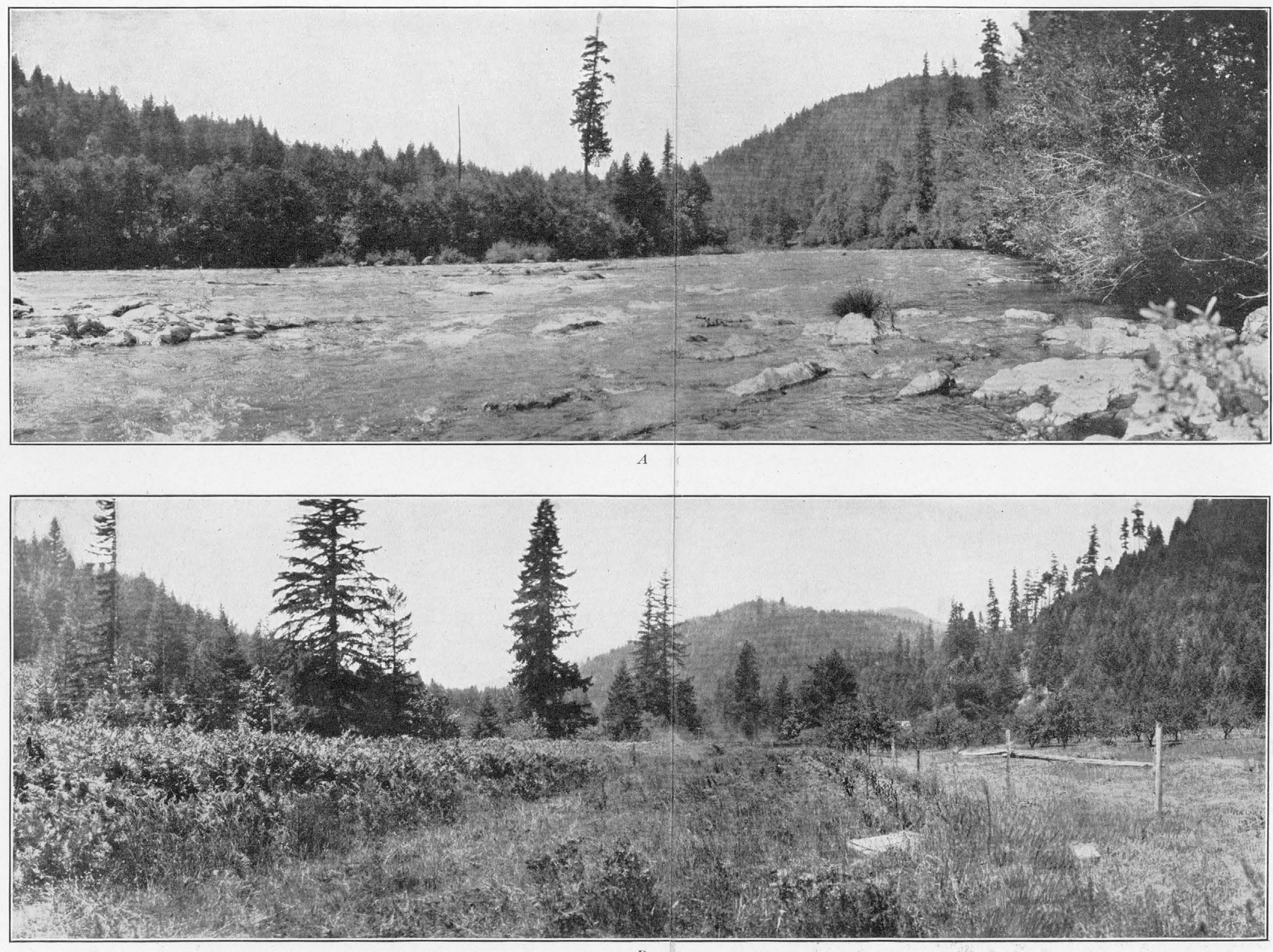

EUGENE MUNICIPAL POWER SITE No. 3, McKENZIE RIVER

$A$, View showing rocks in river channel; $B$, view down the valley, the river to the left. 


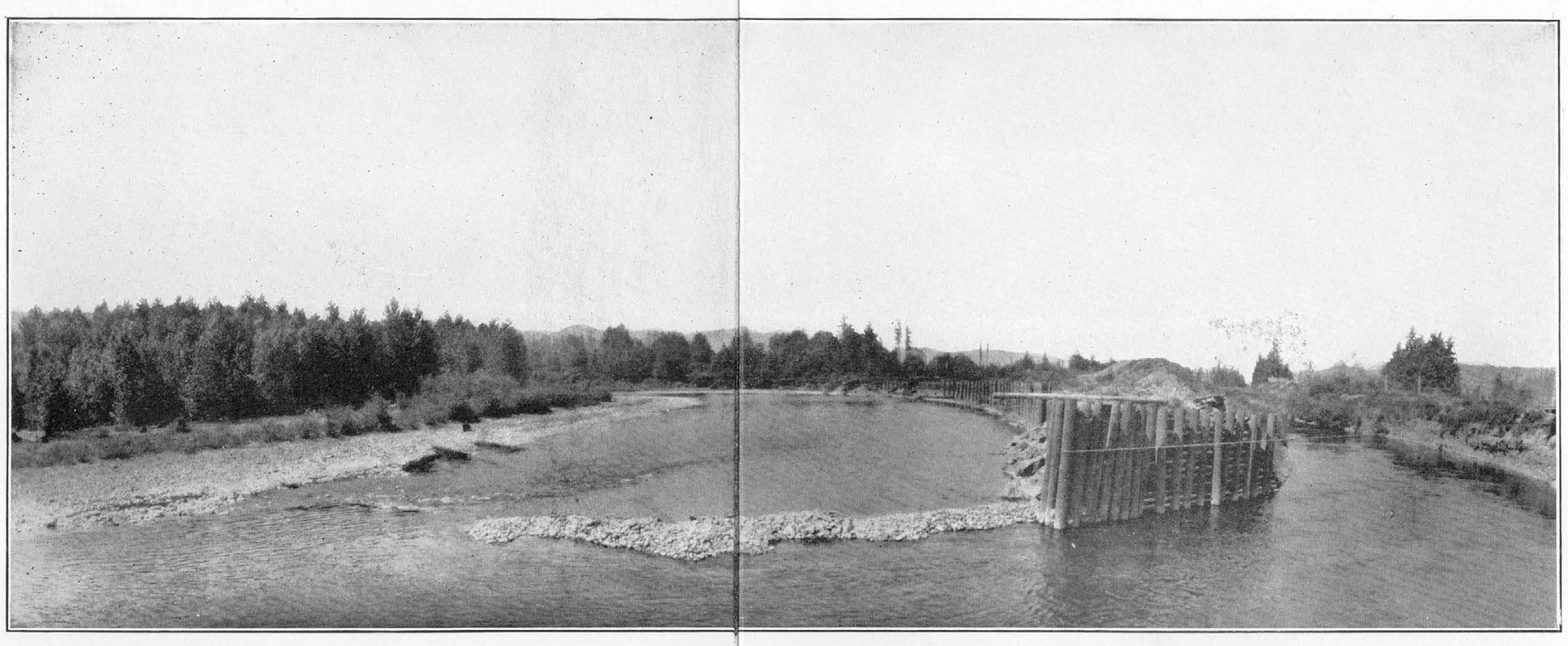

A. EUGENE MUNICIPAL PQWER PLANT No. 1, McKENZIE RIVER Shows diver ion dam and head gates.

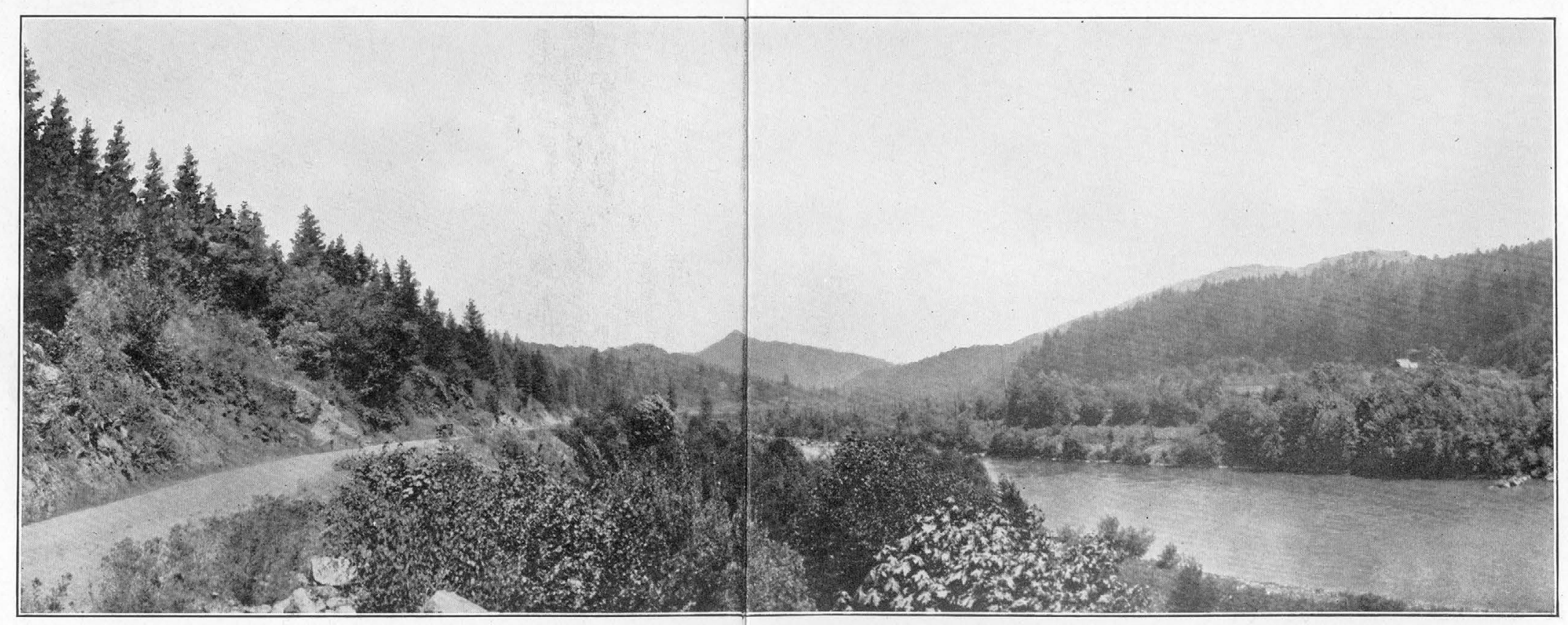

B. MARTIN RAPIDS DAM SITE, LOOKING UPSTREAM 


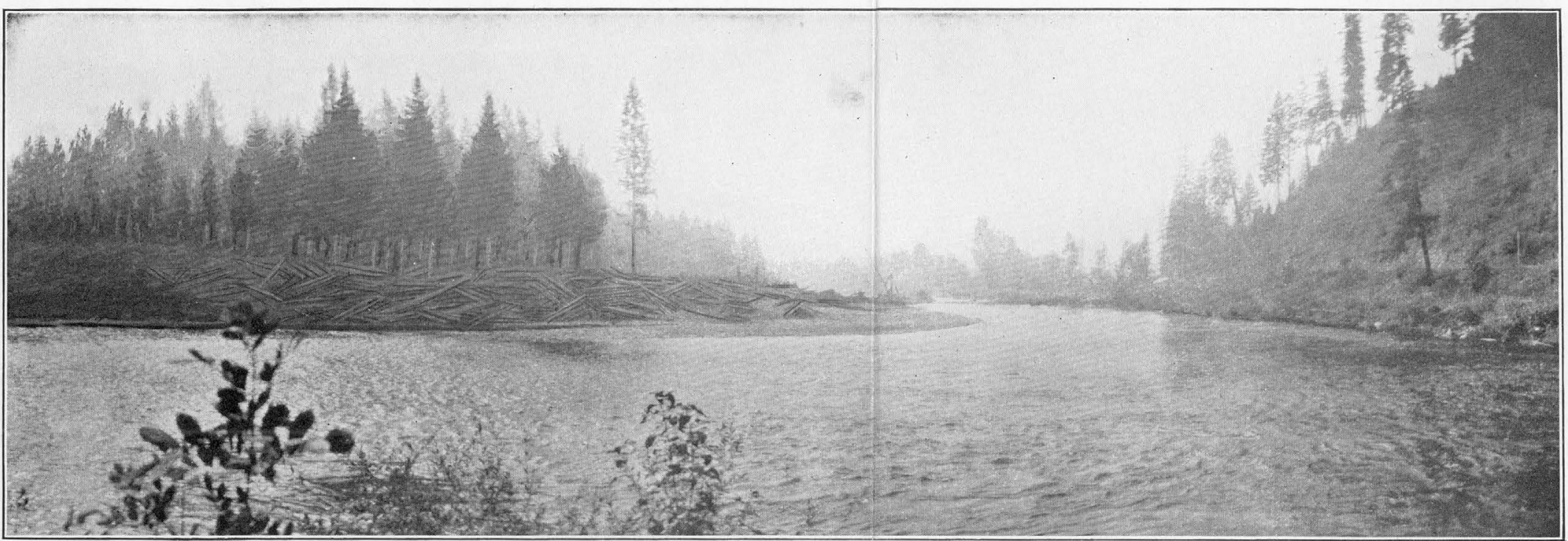

A. EUGENE MUNICIPAL POWER SITE No. 2, MCKENZIE RIVER, DURING CONSTRUCTION OF DIVERSION DAM

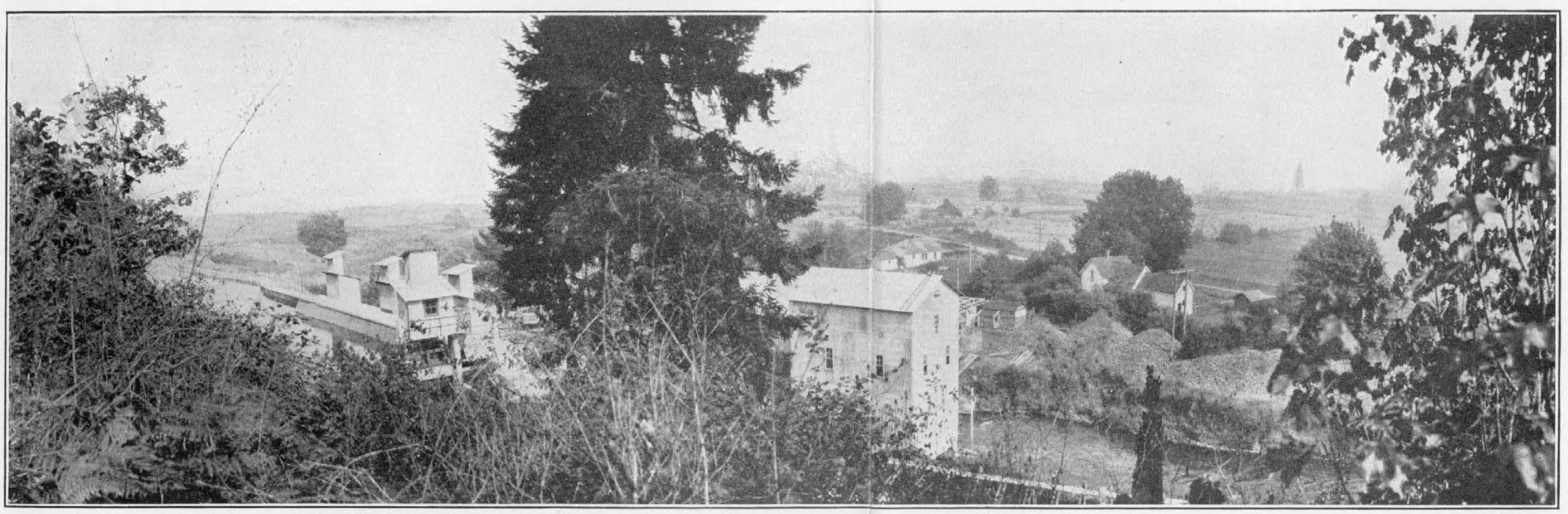

B. EUGENE MUNICIPAL POWER SITE No.

General view, showing headrace to left, tailrace to right. 


\section{BELKN AP POWER SITE (12ND 6)}

The diversion site for the Belknap project is at the mouth of Deer Creek. Water would be carried by a conduit, probably a pipe line, for about 2 miles along the right bank of the river, and then by 2 miles of tunnel to a point in the NE. $1 / 4$ sec. 9, T. 16 S., R. 6 E., where a head of 300 feet would be obtained. About 200 feet of this head would be obtained by the tunnel, which could be made a separate unit if desired.

Any statement of the increase in discharge available for this project over that at the Deer Creek site is little more than a guess, owing to the scantiness of the information available. The Q90 flow at McKenzie Bridge is 340 second-feet greater than the estimated flow available for site 12ND 5. Lost Creek would supply about 225 second-feet, leaving 115 second-feet inflow to be accounted for. It has been assumed that 50 second-feet of this amount would come from Deer Creek and springs between the Smith River and Deer Creek. This would give

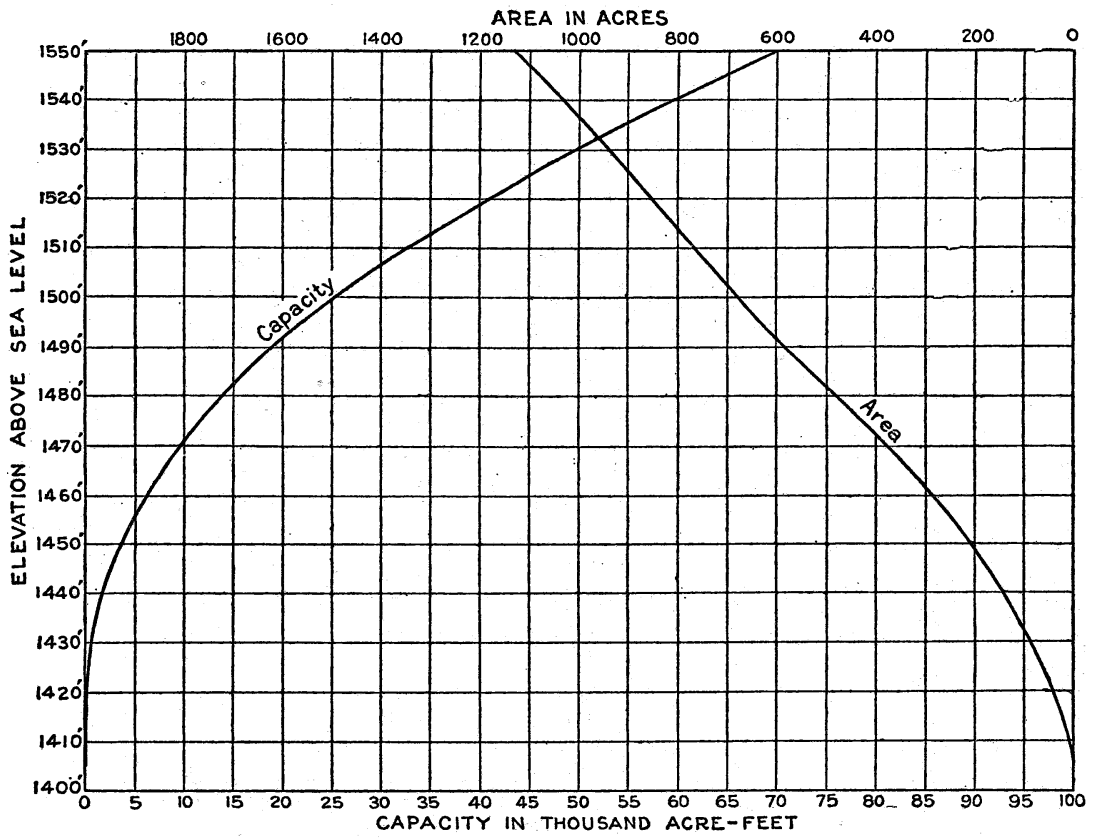

Figure 3.-Area and capacity curves, Paradise reservoir site, McKenzie River Basin

a Q90 flow of 870 second-feet for this project. The Q50 flow is estimated from the Q90 flow by using the ratio of Q50 to Q90 at McKenzie Bridge. It is proposed to divert the flow of Lost Creek (see 12ND 18) at the 1,800-foot contour and carry it to a power house on the left bank of the river opposite the power house of the Belknap site. If desired, the water could be brought across the river so that one power house would serve for both units.

The 'natural Q90 flow at this site is 870 second-feet and the Q50 flow 1,190 second-feet. With a head of 300 feet 20,900 horsepower could be developed for 90 per cent of the time and 28,600 horsepower for 50 per cent of the time.

\section{PARADISE POWER SITE (12ND 7)}

The Paradise site could be developed at the least cost by a conduit, but a dam 145 feet high at mile 66 , in the NW. $1 / 4$ sec. 18 , T. 16 S., R. 6 E., would raise the water level to 1,550 feet and create a reservoir with a capacity of 70,000 acrefeet (see fig. 3), of which 60,000 acre-feet would be in the upper 80 feet. Such a 
dam would be 3,000 feet long, and an earth-fill structure would require over $4,000,000$ cubic yards of material.

No bedrock is exposed in the river channel, which probably consists of glacial material. Both banks rise steeply at the dam site, and probably rock is not more than 10 or 15 feet below the surface. The depth of the gravel deposit in the river channel and on the bottom land on the right bank would determine the feasibility of the project, but at best it would be a very expensive development.

The stored water would generate $44,000,000$ kilowatt-hours at this and other proposed sites lower down on the McKenzie River. If the period of drawdown is assumed to be four months the loss of power due to loss of head would amount to about $8,000,000$ kilowatt-hours, leaving a net development of $36,000,000$ kilowatt-hours. As the stored water would generate 4,500,000 kilowatt-hours at this site, the net loss at the site due to drawing down the head for storage would be 3,500,000 kilowatt-hours.

Under present conditions in Oregon it is not financially feasible to utilize this storage, but there is a possibility that conditions 25 years or more from now may justify its cost. If the power is not developed by means of a dam it can de developed by a conduit, which would provide potential power with natural flow nearly as great as if it were developed by a dam. The natural flow at the dam site is practically the same as at the gaging station at McKenzie Bridge.

Potential power at site 12ND 7

[Gross head, 145 feet; mean head with 80 feet drawdown, 111 feet; regulation for uniform flow]

\begin{tabular}{|c|c|c|c|c|}
\hline \multirow[t]{2}{*}{ · } & \multicolumn{2}{|c|}{ Flow in second-feet } & \multicolumn{2}{|c|}{ Horsepower } \\
\hline & $\begin{array}{l}90 \text { per cent } \\
\text { of time }\end{array}$ & $\begin{array}{l}50 \text { per cent } \\
\text { of time }\end{array}$ & $\begin{array}{l}90 \text { per cent } \\
\text { of time }\end{array}$ & $\begin{array}{c}50 \text { per cent } \\
\text { of time }\end{array}$ \\
\hline $\begin{array}{l}\text { Natural flow } \\
\text { Regulated flow }\end{array}$ & $\begin{array}{l}1,160 \\
1,300\end{array}$ & $\begin{array}{l}1,590 \\
1,590\end{array}$ & $\begin{array}{l}13,400 \\
11,500\end{array}$ & $\begin{array}{l}18,400 \\
18,400\end{array}$ \\
\hline
\end{tabular}

The greatest recorded flow at this site was 8,600 second-feet. Very little valuable land would be overflowed by this proposed reservoir, and there would be little damage to the scenic beauty of the site.

\section{MCKENZIE BRIDGE POWER SITE (12ND 8)}

A diversion dam about 10 feet high at mile 65.5, in the NE. 1/4 sec. 13, T. 16 S., R. 5 E., would back water within 5 feet of the power house of the Paradise site (12ND 7). It is proposed to divert Horse Creek into the McKenzie River above this dam, so that the Q90 flow would be at least 250 second-feet greater than the natural flow at McKenzie Bridge. The water would be carried by a conduit down the right bank of the river for 6 miles, to the mouth of Mill Creek, where a head of 225 feet would be obtained. Most of the conduit would probably be an open canal excavated by steam shovel, but the last mile would be on a steep hillside, and a pipe line would probably be necessary.

Potential power at site 12ND 8

[Gross head, 225 feet]

\begin{tabular}{|c|c|c|c|c|}
\hline & \multicolumn{2}{|c|}{ Flow in second-feet } & \multicolumn{2}{|c|}{ Horsepower } \\
\hline & $\begin{array}{c}90 \text { per cent } \\
\text { of time }\end{array}$ & $\begin{array}{l}50 \text { per cent } \\
\text { of time }\end{array}$ & $\begin{array}{l}90 \text { per cent } \\
\text { of time }\end{array}$ & $\begin{array}{l}50 \text { per cent } \\
\text { of time }\end{array}$ \\
\hline $\begin{array}{l}\text { Natural flow } \\
\text { Regulated flow }\end{array}$ & $\begin{array}{l}a 1,410 \\
a 1,550\end{array}$ & $\begin{array}{l}\text { b } 1,940 \\
\text { b } 1,940\end{array}$ & $\begin{array}{l}25,400 \\
27,900\end{array}$ & $\begin{array}{l}34,900 \\
34,900\end{array}$ \\
\hline
\end{tabular}

a Includes 250 second-feet from Horse Creek.

$b$ Includes 350 second-feet from Horse Creek. 
COMBINATION POWER SITE (12ND 9)

A diversion dam about 5 feet high below the mouth of Mill Creek is proposed for a combination project to divert water into a canal on the right bank. A conduit about $5 \frac{1}{2}$ miles long would lead to a power house just above the mouth of the Blue River, where a head of 140 feet would be obtained. The flow of the South Fork of the McKenzie River could be diverted to the McKenzie River above this site by building a canal a little over a mile in length. If the Blue River Reservoir (12ND 34) is constructed, 48,000 acre-feet of water stored on the Blue River would be available for use in this project.

Such measurements of the South Fork of the McKenzie River as are available indicate that the Q90 discharge was about 195 second-feet in 1926, a very dry year, and 245 second-feet in 1927 , a wet year, giving a mean of 220 second-feet. The Q50 discharge is estimated at 350 second-feet.

The water from the Blue River Reservoir would pass through a power house just above the conduit of this project and be discharged into the conduit. The reservoir would probably be completely emptied during the driest period of the year, and the water below an altitude of 1,300 feet would be discharged into the Blue River and used in the plants below. Only the water above an altitude of 1,300 feet could be diverted across the ridge to this power site.

Potential power at site 12ND 9

[Head, 140 feet]

\begin{tabular}{|c|c|c|c|c|}
\hline & \multicolumn{2}{|c|}{ Flow in second-feet } & \multicolumn{2}{|c|}{ Horsepower } \\
\hline & $\begin{array}{l}90 \text { per cent } \\
\text { of time }\end{array}$ & $\begin{array}{l}50 \text { per cent } \\
\text { of time }\end{array}$ & $\begin{array}{c}90 \text { per cent } \\
\text { of time }\end{array}$ & $\begin{array}{l}50 \text { per cent } \\
\text { of time }\end{array}$ \\
\hline $\begin{array}{l}\text { Natural flow } \\
\text { Regulated flow }\end{array}$ & $\begin{array}{l}a 1,680 \\
\text { a } 1,820\end{array}$ & $\begin{array}{l}\text { b } 2,290 \\
\text { b } 2,290\end{array}$ & $\begin{array}{l}18,800 \\
20,400\end{array}$ & $\begin{array}{l}25,600 \\
25,600\end{array}$ \\
\hline
\end{tabular}

a Includes 250 second-feet from Horse Creek and 220 second-feet from the South Fork of the McKenzie River.

$b$ Includes 350 second-feet each from Horse Creek and the South Fork of the McKenzie River.

RUGENE MUNICIPAL POWER SITE No, 3 (12ND 10)

The Eugene municipal power site No. 3 is in the SW. $1 / 4$ sec. 32, T. 16 S., R. 3 E., just above Bear Creek. (See pl. 7.) A masonry dam is proposed to raise the water $\mathbf{1 7 0}$ feet. The south bank at the site is a brush-covered rock wall of the preglacial McKenzie River Valley and will form a good abutment for the proposed dam. A reef of rock crosses the river in this vicinity, and a specimen from an outcrop in the river was determined under the microscope by C. S. Ross, of the United States Geological Survey, to be andesite. The rock is fresh and dense wherever exposed, and although somewhat jointed it will form an excellent foundation for the proposed dam. The right abutment is a broad bench about 300 feet wide of Pleistocene alluvium, which, wherever it is exposed, consists almost entirely of large cobbles. North of the gravel bench there is a rocky cliff with a short talus at its base. A specimen from the cliff was determined by Mr. Ross to be a diorite. It is apparently intruded into diabase. The contacts are all tight, and so far as the rock is concerned this site is an excellent location. The problem is entirely one of the cost of excavating the gravel bench. Test pits have been put down to bedrock in this bench by the city of Eugene, and it is reported by local people that the altitude of the bedrock under the bench is lower than that of the rock in the river. Such a condition is not surprising, for the ancient channel before it was filled with glacial outwash may well have been cut deeper in bedrock than the present one. Geologically the site is perfectly feasible. 
An alternative site for the dam is at Martin Rapids (see pl. 8, B), in the SW. $1 / 4$ sec. 36, T. $16 \mathrm{~S}$., R. 2 E. At this site a series of conformable lava beds dipping upstream are exposed. The uppermost bed is a feldspar porphyry, determined by C. S. Ross to be a coarse andesite. Below this is a bed of green felsite also determined by Mr. Ross to be an andesite. Under this andesite is a dark igneous rock which is probably a diabase. A narrow gravel bench borders the river on the south abutment, and beyond this are outcrops of sound rock. The north abutment is a rocky cliff composed of the igneous rocks described above. The rock is jointed, but seepage under and around the dam can easily be prevented by cement grouting. The river at the site flows quietly, suggesting a deep channel. The Oregon Power Co., which drilled this site, is reported to have found bedrock between 30 and 40 feet below the surface of the river. Except for the possibly great depth to bedrock this dam site is an excellent one, and it should be carefully investigated before abandonment. If the dam is built at the Eugene municipal site No. 3, then the power between the two sites could be developed by a canal.

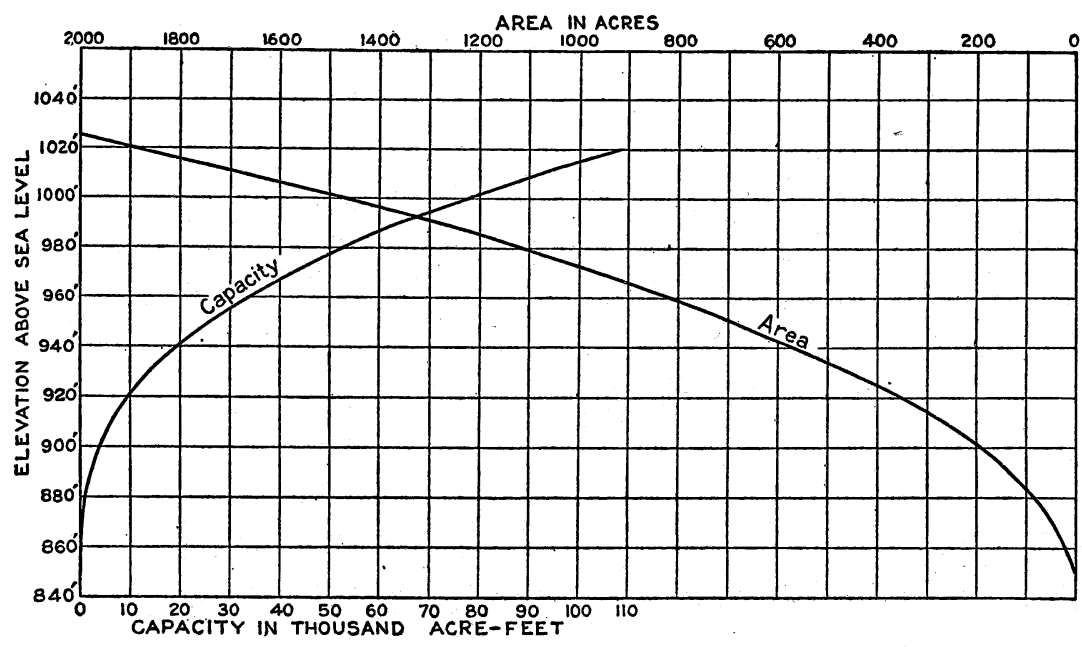

Frgore 4.-Arsa and capacity curves, Eugene municipal site No. 3, McKenzie River Basin

The indications are that the municipal site is the better of the two. The dam proposed at that site would raise the water to an altitude of 1,020 feet. This would create a reservoir with a capacity of 109,000 acre-feet (see fig. 4), of which 90,000 acre-feet would be in the upper 80 feet. This water could be used through a mean head of 138 feet and would generate at 70 per cent efficiency 9,000,000 kilowatt-hours. The stored water could also be used through 430 feet of head at sites lower down the river and would generate 28,000,000 kilowatt-hours, or a total at all sites of $37,000,000$ kilowatt-hours. If it is assumed that the period of drawdown would last four months and that the flow during this period would average 1,800 second-feet, the loss of power due to loss of head would amount to $10,000,000$ kilowatt-hours. Thus there would be an actual loss of 1,000,000 kilowatt-hours at the site itself due to drawing down the head, but the stored water would permit the adjustment of the power supply to the load during the period of low flow, and if the sites below were developed there would be the further advantage of a net gain of 27,000,000 kilowatt-hours. The gaging station near Vida shows the flow at this site. 
Potential power at site $12 N D 10$

[Head without drawdown, 170 feet; mean head with 80 feet drawdown, 138 feet; regulation for uniform flow]

\begin{tabular}{|c|c|c|c|c|}
\hline & \multicolumn{2}{|c|}{ Flow in second-feet } & \multicolumn{2}{|c|}{ Horsepower } \\
\hline & $\begin{array}{c}90 \text { per cent } \\
\text { of time }\end{array}$ & $\begin{array}{c}50 \text { per cent } \\
\text { of time }\end{array}$ & $\begin{array}{c}90 \text { per cent } \\
\text { of time }\end{array}$ & $\begin{array}{c}50 \text { per cent } \\
\text { of time }\end{array}$ \\
\hline $\begin{array}{l}\text { Natural flow } \\
\text { With storage at this site } \\
\text { With storage at all proposed sites }\end{array}$ & $\begin{array}{l}1,750 \\
2,180 \\
2,600\end{array}$ & $\begin{array}{l}3,150 \\
3,150 \\
3,150\end{array}$ & $\begin{array}{l}23,800 \\
24,100 \\
28,700\end{array}$ & $\begin{array}{l}42,800 \\
42,800 \\
42,800\end{array}$ \\
\hline
\end{tabular}

VIDA POWER SITE (12ND 11)

Water for the Vida project would be diverted just below the power house of the Eugene municipal site No. 3 (12ND 10) and carried along the left bank of the river to a power house at mile 37, in the NE. $1 / 4$ SE. $1 / 4$ sec. 29, T. 16 S., R. 2 E., giving a gross head of 100 feet. The flow would be the same as for the municipal power site No. 3. The conduit would be difficult to construct in places, but this project will probably be financially feasible as soon as there is a market for the power. The conduit would be about $6 \frac{1}{2}$ miles in length.

Potential power at site 12ND 11

\begin{tabular}{|c|c|c|c|c|}
\hline & \multicolumn{2}{|c|}{ Flow in second-feet } & \multicolumn{2}{|c|}{ Horsepower } \\
\hline & $\begin{array}{c}90 \text { per cent } \\
\text { of time }\end{array}$ & $\begin{array}{c}50 \text { per cent } \\
\text { of time }\end{array}$ & $\begin{array}{c}90 \text { per cent } \\
\text { of time }\end{array}$ & $\begin{array}{l}50 \text { per cent } \\
\text { of time }\end{array}$ \\
\hline $\begin{array}{l}\text { Natural flow } \\
\text { With storage at Eugene municipal site No. } 3 \\
\text { With storage at all proposed sites }\end{array}$ & $\begin{array}{l}1,750 \\
2,180 \\
2,600\end{array}$ & $\begin{array}{l}3,150 \\
3,150 \\
3,150\end{array}$ & $\begin{array}{l}14,000 \\
17,400 \\
20,800\end{array}$ & $\begin{array}{l}25,200 \\
25,200 \\
25,200\end{array}$ \\
\hline
\end{tabular}

\section{EUGENE MUNICIPAL POWER SITE NO. 2 (12ND 12)}

The project at Eugene municipal power site No. 2 is under construction by the city. (See pl. 9, A.) Water will be diverted by a 20 -foot concrete dam in the NE. $1 / 4$ sec. 31 , T. 16 S., R. 2 E., at mile 35.5 and carried in a conduic along the right bank to a power house in the SE. $1 / 4$ sec. 9, T. 17 S., R. 1 E., at mile 30, which will give a gross head of 90 feet. The conduit will be an unlined canal for most of the distance, but probably the over-all efficiency will be at least 70 per cent, which is the efficiency assumed in computing the potential power. The flow would be somewhat greater than at the gaging station at Vida.

Two units are planned, of which only one will be installed at first. Each unit will consist of a 10,000-horsepower turbine with a 7,500-kilovolt-ampere generator. The canal will have a capacity of 2,200 second-feet. Two penstocks 12 feet in diameter will extend 275 feet from the forebay to the power house.

The city of Eugene plans to allow at least 300 second-feet to flow past the dam unused at all seasons of the year, it being the intention to avoid thereby any injury to the scenic and recreational features of the river channel between the points of diversion and return of the water utilized for power development. This reserve will not affect the potential power of the site, however, but only the operation of the power plant. In case of an emergency or for any other good reason the water could all be diverted and used. 
Potential power at site 12ND 12

[Head, 90 feet]

\begin{tabular}{|c|c|c|c|c|}
\hline & \multicolumn{2}{|c|}{ Flow in second-feet } & \multicolumn{2}{|c|}{ Horsepower } \\
\hline & $\begin{array}{c}90 \text { per cent } \\
\text { of time }\end{array}$ & $\begin{array}{l}50 \text { per cent } \\
\text { of time }\end{array}$ & $\begin{array}{c}90 \text { per cent } \\
\text { of time }\end{array}$ & $\begin{array}{l}50 \text { per cent } \\
\text { of time }\end{array}$ \\
\hline $\begin{array}{l}\text { Natural flow } \\
\text { With storage at Eugene municipal site No. } 3 \\
\text { With storage at all proposed sites. }\end{array}$ & $\begin{array}{l}1,780 \\
2,210 \\
2,640\end{array}$ & $\begin{array}{l}3,350 \\
3,350 \\
3,350\end{array}$ & $\begin{array}{l}12,800 \\
15,900 \\
19,000\end{array}$ & $\begin{array}{l}24,100 \\
24,100 \\
24,100\end{array}$ \\
\hline
\end{tabular}

DEERHORN POWER SITE (12ND 13)

The Deerhorn site includes the stretch of river between the power house of the Eugene municipal plant No. 2 (12ND 12), below Leaburg, now being built, and the point of diversion of the Eugene plant No. 1 (12ND 14), already constructed. Water would be diverted just below the Leaburg site and carried along the right bank of the river to a power house in the NW. $1 / 4$ sec. 24, T. 17 S., R. 1 W., giving a gross head of 45 feet. Tail water from this plant would be discharged directly into a canal leading to Eugene power plant No. 1. The water available at this site is assumed to be 10 second-feet less than the flow at Hendricks Bridge for 90 per cent of the time and 20 second-feet less for 50 per cent of the time.

Potential power at site 12ND 13

[Gross head, 45 feet]

\begin{tabular}{|c|c|c|c|c|}
\hline & \multicolumn{2}{|c|}{ Flow in second-feet } & \multicolumn{2}{|c|}{ Horsepower } \\
\hline$\cdot$ & $\begin{array}{l}90 \text { per cent } \\
\text { of time }\end{array}$ & $\begin{array}{l}50 \text { per cent } \\
\text { of time }\end{array}$ & $\begin{array}{c}90 \text { per cent } \\
\text { of time }\end{array}$ & $\begin{array}{l}50 \text { per cent } \\
\text { of time }\end{array}$ \\
\hline $\begin{array}{l}\text { Natural flow } \\
\text { With storage at Eugene municipal site No. } 3 \\
\text { With storage at all proposed sites }\end{array}$ & $\begin{array}{l}1,790 \\
2,220 \\
2,650\end{array}$ & $\begin{array}{l}3,550 \\
\mathbf{3}, 550 \\
\mathbf{3}, 550\end{array}$ & $\begin{array}{l}6,440 \\
8,000 \\
9,540\end{array}$ & $\begin{array}{l}12,800 \\
12,800 \\
12,800\end{array}$ \\
\hline
\end{tabular}

HAYDEN BRIDGE POWER SITE (12ND 15)

Water for the Hayden Bridge site would be diverted just below the Eugene municipal power plant No. 1 and carried by a conduit to a point near Hayden Bridge, in the SW. $1 / 4$ sec. 20 , T. 17 S., R. 2 W., giving a gross head of 90 feet. This project would involve $6 \frac{1}{2}$ miles of conduit, compared with $5 \frac{1}{2}$ miles for Eugene municipal site No. 2 (12ND 12). There would be no dam to construct, as the conduit could be made a continuation of the tailrace of Eugene plant No. 1 . A siphon about a quarter of a mile long would be necessary at Camp Creek, but the head on the siphon would amount to only about 30 feet. The power plant would be only 11 miles from the mouth of the McKenzie River, on the Southern Pacific Railroad. Altogether this seems to be an inexpensive development and financially feasible whenever a market is ready for the power. The water available would be the same as for the Eugene municipal plant No. 1 (12ND 14).

Potential power at site $12 N D 15$

[Gross head, 90 feet]

\begin{tabular}{|c|c|c|c|c|}
\hline & \multicolumn{2}{|c|}{ Flow in second-feet } & \multicolumn{2}{|c|}{ Horsepower } \\
\hline & $\begin{array}{c}90 \text { per cent } \\
\text { of time }\end{array}$ & $\begin{array}{l}50 \text { per cent } \\
\text { of time }\end{array}$ & $\begin{array}{l}90 \text { per cent } \\
\text { of time }\end{array}$ & $\begin{array}{l}50 \text { per cent } \\
\text { of time }\end{array}$ \\
\hline $\begin{array}{l}\text { Natural flow } \\
\text { With storage at Eugene municipal site No. } \\
\text { With storage at all proposed sites }\end{array}$ & $\begin{array}{l}1,790 \\
\mathbf{2}, 220 \\
\mathbf{2}, 650\end{array}$ & $\begin{array}{l}3,500 \\
3,500 \\
3,500\end{array}$ & $\begin{array}{r}12,900 \\
16,000 \\
19,000\end{array}$ & $\begin{array}{l}25,200 \\
25,200 \\
25,200\end{array}$ \\
\hline
\end{tabular}




\section{COBURG POWER SITE (12ND 16)}

Water for the Coburg site would be diverted by a dam 10 feet high just below the mouth of the Mohawk River and carried along the right bank of the McKenzie River for 5 miles to the Coburg Bridge, giving a gross head of 50 feet. A long dam on a gravel foundation would be required. The water available is assumed to be 10 second-feet more than at Hendricks Bridge for 90 per cent of the time and 20 second-feet more for 50 per cent of the time. The canal could be dug with a steam shovel but would probably require lining at the lower end. The power house would be close to Springfield and Eugene, and only a short transmission line would be required. This appears to be a feasible development as soon as a market for the power is available.

Potential power at site $12 N D 16$

[Gross head, 50 feet]

\begin{tabular}{|c|c|c|c|c|}
\hline & \multicolumn{2}{|c|}{ Flow in second-feet } & \multicolumn{2}{|c|}{ Horsepower } \\
\hline & $\begin{array}{c}90 \text { per cent } \\
\text { of time }\end{array}$ & $\begin{array}{c}50 \text { per cent } \\
\text { of time }\end{array}$ & $\begin{array}{c}90 \text { per cent } \\
\text { of time }\end{array}$ & $\begin{array}{l}50 \text { per cent } \\
\text { of time }\end{array}$ \\
\hline $\begin{array}{l}\text { Natural flow } \\
\text { With storage at Eugene municipal site No. 3 } \\
\text { With storage at all proposed sites. }\end{array}$ & $\begin{array}{l}1,810 \\
2,240 \\
2,670\end{array}$ & $\begin{array}{l}3,590 \\
3,590 \\
3,590\end{array}$ & $\begin{array}{r}7,440 \\
8,840 \\
10,700\end{array}$ & $\begin{array}{l}14,400 \\
14,400 \\
14,400\end{array}$ \\
\hline
\end{tabular}

\section{OLALLIE CREEK POWER SITE (12ND 17)}

Water can be diverted from the springs that contribute the entire low-water flow of Olallie Creek at an altitude of 2,160 feet and carried in a conduit along the left bank of the creek for about a mile to a power house where a head of 140 feet can be obtained. Water from the power house will be discharged into the conduit of the Deer Creek power site (12ND 5). The following miscellaneous discharge measurements have been made near the mouth of the creek:

\begin{tabular}{|c|c|}
\hline Second-feet & Second-feet \\
\hline Apr. 30, 1924 & July 20, 1926 \\
\hline $\begin{array}{l}\text { May 13, } 1924 \\
\text { Aug. 12, } 1924\end{array}$ & Sept. 6, 1926_.. 139 \\
\hline
\end{tabular}

As both 1924 and 1926 were years of very low run-off it is assumed that the Q90 flow amounts to 165 second-feet and that the Q50 flow amounts to 200 second-feet. With a gross head of 140 feet 1,850 horsepower could be developed for 90 per cent of the time and 2,240 horsepower for 50 per cent of the time.

\section{LOST CREEK POWER SITE (12ND 18)}

Lost Creek receives most of its low-water flow from springs near the mouth of White Branch. By diverting it at the 1,800-foot contour crossing, practically the whole flow of Lost Creek would be obtained. The water would be carried by a conduit along the left bank of Lost Creek and then through a long penstock to a power house in the NE. $1 / 4$ SE. $1 / 4$ sec. 9 , T. 16 S., R. 6 E., where a head of 250 feet would be obtained. If desired it could be carried across the river to the Belknap power house (12ND 6).

A temporary gaging station was maintained on Lost Creek near the mouth in 1926, a very dry year. The records at this station show a Q90 discharge of 173 second-feet, but the Q90 flow in 1926 at McKenzie Bridge was only 67 per cent of the normal flow, and if this was true of Lost Creek then the normal Q90 flow would amount to about 250 second-feet. It has been assumed that the Q90 flow is 225 second-feet and the Q50 flow 300 second-feet. 
This project would require about 3 miles of canal and 0.6 mile of penstock. It is close to good roads, the right of way is across lands of little value, and outside of the transmission lines the cost should not be very high. If desired the water could be carried across the McKenzie River to the power house at the Belknap site (12ND 6).

With a head of 250 feet 4,500 horsepower could be developed for 90 per cent of the time and 6,000 horsepower for 50 per cent of the time.

\section{POWER SITES ON HORSE CREEK ABOVE SEPARATION CREEK (12ND 19, 20, AND 21)}

During periods of low flow most of the water in Horse Creek comes from Separation Creek. For example, on September 9, 1926, the flow of Separation Creek at its mouth was 206 second-feet, and on August 28 Horse Creek above the mouth of Separation Creek was flowing 25 second-feet. Probably in a wet year the flow of Horse Creek would be considerably higher, but it is doubtful if the Q90 flow above the mouth of Separation Creek would exceed 50 secondfeet. Upstream the flow gradually diminishes until at Horse Lake it amounts to only about 5 second-feet. The area of Horse Lake is roughly 100 acres, and it is estimated that a dam 50 feet high and 500 feet long would store not to exceed 8,000 acre-feet of water.

The fall below Horse Lake amounts to several hundred feet to the mile, but with a low-water flow of not more than 10 second-feet the development of this site will not be economically feasible for many years. No survey of Horse Creek above Separation Creek has been made, and therefore detailed power estimates can not be given, but three sites are proposed, as follows: 12ND 19, at Horse Lake; 12ND 20, from a point about a mile below Horse Lake to the mouth of Eugene Creek; 12ND 21, from the mouth of Eugene Creek to the mouth of Separation Creek. These three sites would have a total potential capacity, without storage, estimated roughly at 4,000 horsepower for 90 per cent of the time and 8,000 horsepower for 50 per cent of the time.

\section{FOLEY SPRITGS POWER SITE (12ND 22)}

Water for the Foley Springs project would be diverted from Horse Creek just below the mouth of Separation Creek and carried along the left bank of the creek to a power house at the 1,700-foot contour crossing, about 1 mile above Foley Springs, where a head of 280 feet would be obtained.

In 1926 the Q90 flow of Horse Creek at the bridge at mile 3 amounted to 250 second-feet. As 1926 was the year of lowest flow recorded in western Oregon, it seems probable that in an ordinary year there would be a $\mathrm{Q} 90$ flow of at least 280 second-feet at the bridge and 275 second-feet at this site. No records are available to show the Q50 flow, but it is estimated roughly at 400 second-feet. It is possible that 5,000 acre-feet of storage would be developed on Mesa Creek, a tributary of Separation Creek, but this would not greatly affect the Q90 flow at the Foley Springs site, and it has been disregarded. With a head of 280 feet 6,160 horsepower could be developed for 90 per cent of the time and 8,960 horsepower for 50 per cent of the time.

\section{POWER SITE AT THE MOUTH OF HORSE CREEK (12ND 28)}

Water for the project at the mouth of Horse Creek would be diverted at the 1,700-foot contour crossing on Horse Creek and carried along the right bank of the creek and through a tunnel to a power house in the NW. $1 / 4$ NE. $1 / 4$ sec. 24, T. 16 S., R. 5 E., where a head of 300 feet would be obtained. Water after passing through the power house would be carried in an open canal to the McKenzie River at the diversion site for project 12ND 8. The Q90 flow available for this project would not be over 5 second-feet greater than the flow just below 
Separation Creek and the Q50 flow 10 second-feet greater. The basis for the estimate of the water available at this site is discussed under site 12ND 22.

The natural Q90 flow at this site is 280 second-feet and the Q50 flow 410 secondfeet. With a head of 300 feet 6,720 horsepower could be developed for 90 per cent of the time and 9,840 horsepower for 50 per cent of the time.

MESA CREEK POWRR SITE (12ND 24)

The Mesa Creek site is near the Three Sisters, at the head of Separation Creek, a tributary of Horse Creek. It is proposed to construct a dam 100 feet high on Separation Creek at the 4,800-foot contour. Water would be diverted into the reservoir thus formed from Mesa Creek and Honey Creek, tributaries of Separation Creek. A penstock about $1 \frac{1}{2}$ miles long would lead to a power house at an altitude of 3,550 feet, giving an average head of 1,300 feet. The capacity of the reservoir would be 5,350 acre-feet, which could be used through a head of 2,870 feet on Separation Creek and a total head of 4,415 feet on the McKenzie River, Horse Creek, and Separation Creek. This amount of stored water would generate 5,000,000 kilowatt-hours of energy if used through a head of 1,300 feet at 70 per cent efficiency and 17,000,000 kilowatt-hours if used through a head of 4,415 feet. The loss of power due to drawing down the head would amount to $1,000,000$ kilowatt-hours. If it is considered better to develop this site without storage the water could be diverted at an altitude of 5,000 feet, giving a total head of 1,450 feet.

Very little information is available on the flow of Separation Creek and its tributaries, Mesa, Honey, Rainbow, and Louisa Creeks. On July 12, 1927, Mesa Creek 1 mile above its mouth was flowing 51 second-feet, and a tributary entering Mesa Creek at an altitude of 4,250 feet was flowing 19 second-feet. Probably most of the flow of this tributary could be diverted and used, as it lies between Mesa Creek and Separation Creek. Separation Creek at the mouth of Mesa Creek was flowing 76 second-feet on July 12 and 76 second-feet on July 20. At an altitude of 5,400 feet it was flowing $\mathbf{5 0}$ second-feet on July 20 . Probably at the 4,800-foot contour the flow was about 60 second-feet. Honey Creek has very little water, but it could be easily diverted into Separation Creek. The flow in July, 1927, available for this project is estimated at 50 second-feet from Mesa Creek, 15 second-feet from a tributary of Mesa Creek, 60 second-feet from Separation Creek, and 7 second-feet from Honey Creek, a total of 132 second-feet. As 1927 was a wet year the flow ordinarily would amount to perhaps threefourths of this, or 100 second-feet, and this is taken as the Q90 flow ordinarily available. No records are available for the winter, but even if the winter flow is low on Separation Creek it is high on most streams in western Oregon, and any load could be carried by other stations.

The flow at the mouth of Separation Creek on July 25, 1927, was 308 secondfeet, and on September 9, 1926, at the end of a very dry season, it was 206 secondfeet. Horse Creek at the highway bridge was flowing 264 second-feet on July 25, 1926, and 235 second-feet on September 9, 1926. It seems safe to assume that the Q90 flow of Separation Creek would be at least three-fourths of the flow measured in July, 1927. There are no records on which to base an estimate of the Q50 flow, but it has been assumed as at least 25 per cent greater than the Q90 flow.

The records of stream flow available are not sufficient to permit an estimate of the potential power for 90 per cent of the time with storage, but the amount of storage available would not afford much increase in the power. Part of this stored water would be required to bring the minimum flow up to the Q90 flow. A plant of this kind with some storage and high head should be valuable in any system to carry the peak load. 


\section{Potential power at site 12ND 24}

[Gross head without storage, 1,450 feet; gross head with storage, 1,300 feet]

\begin{tabular}{|c|c|c|c|c|}
\hline & \multicolumn{2}{|c|}{ Flow in second-feet } & \multicolumn{2}{|c|}{ Horsepower } \\
\hline & $\begin{array}{c}90 \text { per cent } \\
\text { of time }\end{array}$ & $\begin{array}{l}50 \text { per cent } \\
\text { of time }\end{array}$ & $\begin{array}{c}90 \text { per cent } \\
\text { of time }\end{array}$ & $\begin{array}{l}50 \text { per cent } \\
\text { of time }\end{array}$ \\
\hline Natural flow & 100 & 125 & 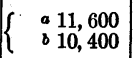 & $\begin{array}{l}\text { a } 14,500 \\
813,000\end{array}$ \\
\hline
\end{tabular}

a Without storage; water diverted at higher altitude than proposed reservoir.

$\checkmark$ With storage.

\section{HARVEY CREEK POWER STTE (12ND 25)}

Water for the Harvey project would be diverted from Separation Creek at an altitude of 3,550 feet, just below the power house of the Mesa site (12ND 24). A conduit about 5 miles long down the right bank of Separation Creek would lead to a power house a third of a mile above Harvey Creek, where a head of 850 feet would be obtained. If an open canal is used for the conduit for this project it probably will have to be lined for most of its length. The flow for this site would be slightly greater than that for the Mesa site.

On July 12, 1927, Separation Creek at the mouth of Mesa Creek was flowing 76 second-feet, and Mesa Creek at the mouth was flowing 80 second-feet. The flow of Honey Creek at the mouth is estimated at 10 second-feet. This gives a total of 166 second-feet available for diversion in July, 1927. The Q90 flow is assumed to amount to three-fourths of this quantity, or 125 second-feet. The Q50 discharge is roughly estimated at 160 second-feet. With a gross head of 850 feet 8,500 horsepower could be developed for 90 per cent of the time and 10,900 horsepower for 50 per cent of the time.

\section{RAINBOW CREEK POWER SITE (12ND 26)}

Detailed studies are necessary to determine the most economical method of developing the Rainbow Creek site. The method proposed would not obtain all the power available, but by combining all the power in one site it would provide economical operation. Harvey Creek can easily be diverted into Separation Creek above the 2,700-foot contour, the point of diversion for this project. A conduit would be carried along the right bank of Separation Creek, and Rainbow Creek and Louisa Creek would be diverted into it, the combined flow being used at a power house at the mouth of Separation Creek, where a head of $\mathbf{7 2 0}$ feet would be obtained. It may be found more economical to split this site into two projects, with one power house between Rainbow and Louisa Creeks and one at the mouth of Separation Creek. This method would allow about 50 second-feet more water to be used in the lower project, which would add about 900 horsepower to the capacity for 90 per cent of the time, but it would require an extra penstock, power house, and power-house machinery, so unless the construction of the conduit on the higher ground would prove too difficult, a single plant will probably be preferred.

In July, 1927, the measured flow of Separation Creek below the mouth of Mesa Creek amounted to 166 second-feet, Louisa Creek at the 3,100-foot contour was flowing 23 second-feet, and Rainbow Creek above the falls 25 second-feet; if the flow of Harvey Creek is estimated at 14 second-feet it gives a total discharge of 228 second-feet. The flow at the mouth of Separation Creek was 308 second-feet, and probably 20 second-feet of this difference enters Separation Creek above Harvey Creek and below Mesa Creek. This gives a total dis- 
charge in July, 1927, of 248 second-feet. On the assumption, as for the other sites, that the Q90 flow equals three-fourths of the flow in July, 1927, it is 186 second-feet. The Q50 flow is estimated at roughly 25 per cent more than the Q90 flow, or 235 second-feet. This estimate of the Q50 flow is probably low, but it is conservative. With a gross head of 720 feet, 10,700 horsepower could be developed for 90 per cent of the time and 13,500 horsepower for 50 per cent of the time.

The power that could be obtained from water stored above Mesa Creek is discussed under site $12 \mathrm{ND} 24$. These data are not sufficient to justify an estimate of the power for 90 per cent of the time with storage.

ELK CREEK POWER SITE (12ND 27)

The Elk Creek project involves a diversion dam on the South Fork of the McKenzie River just below the mouth of Elk Creek. A conduit about 21/2 miles long would lead to the power house at the mouth of the Roaring River, where, according to the topographic map of the Waldo Lake quadrangle, a head of 250 feet would be obtained. On July 28, 1927, the flow at the mouth of Elk Creek was 76 second-feet, and the Q90 discharge is estimated at 70 second-feet from this measurement and fragmentary records of the flow above the East Fork in 1926 and 1927. The Q50 discharge is estimated roughly at 105 secondfeet. These estimates may be considerably in error, but they afford some idea of the power value of this site. With a gross head of 250 feet 1,400 horsepower could be developed for 90 per cent of the time and 2,100 horsepowerfor 50 per cent of the time.

\section{AUGUSTA CREER POWER SITE (12ND 28)}

Water for the Augusta Creek project would be diverted from the South Fork of the McKenzie River at the mouth of the Roaring River, at an altitude of about 2,550 feet. (See map of the Waldo Lake quadrangle.) A conduit about 6 miles long would lead to the mouth of Augusta Creek, where a head of 430 feet would be obtained.

On July 23, 1926, the flow of the South Fork below Augusta Creek amounted to 168 second-feet, of which perhaps 5 second-feet came from Augusta Creek. On July 28, 1927, the South Fork below Elk Creek was flowing 76 second-feet, and on July 29 the Roaring River was flowing 126 second-feet, a total of 202 second-feet. The Q90 flow at this site is estimated at 180 second-feet from these measurements and fragmentary records on the South Fork of the McKenzie River above the East Fork in 1926 and 1927. The Q50 flow is estimated roughly at 50 per cent more than the $\mathrm{Q} 90$ flow, or 270 second-feet. With a gross head of 430 feet 6,200 horsepower could be developed for 90 per cent of the time and 9,300 horsepower for 50 per cent of the time.

\section{HARDY CREEK POWER SITE (12ND 29)}

Water for the Hardy Creek project would be diverted from the South Fork of the McKenzie River at about mile 17, just below Augusta Creek, and carried by a conduit to a point above the mouth of Hardy Creek, where a head of 290 feet would be obtained. The water available at this site would be the same as for the Augusta site (12ND 28), with the addition of that from Augusta Creek, which is estimated roughly to have a Q90 flow of 5 second-feet and a Q50 flow of 10 second-feet. The natural Q90 flow of the South Fork at the Hardy Creek site is thus 185 second-feet, and the Q50 flow 280 second-feet. With a gross head of 290 feet 4,300 horsepower could be developed for 90 per cent of the time and 6,500 horsepower for 50 per cent of the time. 


\section{SLIDE CREEK POWER SITE (12ND 30)}

Water for the Slide Creek project would be diverted from the South Fork of the McKenzie River just above the mouth of Hardy Creek, at mile 121/2, and carried by a conduit for $3 \frac{1}{2}$ miles to a point near the mouth of Slide Creek, where a head of 220 feet would be obtained. The Q90 flow at this site would be practically the same as for the Hardy Creek site, or 185 second-feet. The Q50 flow is estimated at 5 second-feet greater than that for the Hardy Creek site, or 285 second-feet. With a gross head of 220 feet 3,250 horsepower could be developed for 90 per cent of the time and 5,000 horsepower for 50 per cent of the time. Perhaps a pressure pipe line near the river would be less expensive than a conduit along the 1,820-foot contour as proposed.

\section{EAST FORK POWER SITE (12ND 31)}

Water for the East Fork site would be diverted from the South Fork of the McKenzie River just above the mouth of Slide Creek, at mile 9.1, and carried by a conduit for nearly 4 miles to a point above the East Fork of the South Fork, where a head of 265 feet would be obtained. A number of creeks enter between the point of diversion for this site and the Slide Creek power site (12ND 30), but their flow is not great. The Q90 flow below the mouth of the East Fork is estimated from fragmentary records at 195 second-feet in 1926 and 245 second-feet in 1927, or a mean of 220 second-feet. The Q90 flow at this site is estimated at 200 secondfeet and the Q50 flow at 300 second-feet. With a head of 265 feet 4,240 horsepower could be developed for 90 per cent of the time and 6,360 horsepower for 50 per cent of the time.

\section{COUGAR CREEK POWER SITE (12ND 32)}

Water for the Cougar Creek site would be diverted from the South Fork of the McKenzie River just below the mouth of the East Fork and carried by a conduit to a point opposite the 1,200-foot contour crossing at mile 3, where a head of 120 feet would be obtained. The flow at this site would be increased by the flow of the East Fork. In 1926 this amounted to 11 second-feet on June 16, 1.7 second-feet on August 8, and 11 second-feet on September 22. In an average year the Q90 flow of the East Fork would probably amount to 8 second-feet and the Q50 flow to 15 second-feet. The natural Q90 flow at this site is 208 second-feet and the Q50 flow 315 second-feet. With a head of 120 feet 2,000 horsepower could be developed for 90 per cent of the time and 3,050 horsepower for 50 per cent of the time.

\section{ROARING RIVER POWER SITE (12ND 38)}

The Roaring River supplies nearly 60 per cent of the low-water flow of the South Fork of the McKenzie River. This stream is shown on the topographic map of the Waldo Lake quadrangle. On July 29, 1927, a current-meter measurement showed a discharge of 126 second-feet. By diverting the two forks of the Roaring River at the 3,400-foot contour crossing with about 4 miles of conduit a head of 850 feet could be obtained. Probably the low-water flow at the proposed point of diversion would be almost as great as that at the mouth. The Q90 flow at the mouth is estimated at 115 second-feet, and that at the point of diversion at 100 second-feet. A road is being built up the South Fork of the McKenzie River, and this project appears to be feasible for the not distant future. The natural Q90 flow at this site is estimated at 100 second-feet and the Q50 flow at 150 second-feet. With a head of 850 feet 6,800 horsepower could be developed for 90 per cent of the time and 10,200 horsepower for 50 per cent of the time. 


\section{BLUE RIVER POWER SITE (12ND 34)}

The plant at the Blue River site would be built primarily to use the water stored in the Blue River reservoir. (See p. 106.) The water would be carried in a penstock about half a mile long to a power house on the McKenzie River, in the NE. $1 / 4$ NE. $1 / 4$ sec. 23 , T. 16 S., R. 4 E., where a head of 125 to 225 feet would be obtained. Only the water stored at an altitude of more than 1,300 feet, amounting to 49,000 acre-feet, could be used at this site, and with an average head of 185 feet it would generate 6,500,000 kilowatt-hours of power. Water from the plant would be discharged into the conduit of the combination project 12ND 9 at an altitude of 1,175 feet.

It would be possible to use this site to develop power from the natural flow of the Blue River, but it would not be feasible to build so expensive a project for the amount of water available. There are very few data on which to base an estimate of the Q90 or Q50 flow of the Blue River. On August 14, 1924, the discharge 1 mile above the mouth was 18 second-feet. On August 8, 1926, the discharge at a point near the mouth was 16 second-feet, and on June 17, 1926, it was 50 second-feet. Both 1924 and 1926 were very dry years, and it is assumed that the Q90 flow is 25 second-feet and the Q50 flow 50 second-feet. With a head of 200 feet 400 horsepower could be developed for 90 per cent of the time and 800 horsepower for 50 per cent of the time.

The stored water would be used not to equalize the flow of the Blue River but in connection with the sites on the McKenzie River. The total amount of power that could be obtained from the stored water is given in connection with the Blue River reservoir site. (See p. 106.)

\section{MARKET}

The power developed at present on the McKenzie River is all used in the city of Eugene. The total resources of the basin without storage, however, amount to 290,000 horsepower for 90 per cent of the time and 444,000 horsepower for 50 per cent of the time. This amount of potential power in a modern interconnected power system, with steam stand-by plants to carry the load in dry seasons, would produce nearly 2,000,000,000 kilowatt-hours of usable power. This is more than twice the total amount of power produced by publicutility and municipal plants in the State of Oregon in 1927. The complete development of the resources of the McKenzie River Basin is a long way in the future if the power is used only to supply the ordinary lighting and manufacturing load in the vicinity. At present there seems no inclination on the part of privately owned companies to start development on the McKenzie River, and unless this is done the only market for power is Eugene.

The ordinary growth of the lighting and power load in Eugene without the introduction of extraordinary development of market for power may require new plants on the McKenzie River, such as those considered herein, at intervals of approximately 10 or 15 years. The introduction of new industries, such as the electrochemical and electrometallurgical industries, which are large consumers of power, may bring more rapid development of these power resources. 
124 CONTRIBUTIONS TO HYDROLOGY OF UNITED STATES, 1930

Power from this river could be economically developed and transmitted to Portland, but that market is already well supplied, and many other supplementary sites are available. The probabilities are therefore that only a part of the potential power resources of the McKenzie River will be developed in the near future. 